\title{
To Be or Not to Be Listed? A Dilemma of the Greek-Owned Cyclical Shipping Companies
}

\author{
Alexandros M. Goulielmos ${ }^{1,2}$ \\ ${ }^{1}$ Former Professor of Marine Economics, University of Piraeus, Department of Maritime Studies, Faculty of Maritime and \\ Industrial Studies, Piraeus, Greece \\ ${ }^{2}$ Professor Emeritus of Shipping, Transport and Logistics Department, Business College of Athens, Athens, \\ Greece \\ Email: ag@unipi.gr, am.goulielmos@hotmail.com, agoulielmos@bca.edu.gr
}

How to cite this paper: Goulielmos, A. M. (2021). To Be or Not to Be Listed? A Dilemma of the Greek-Owned Cyclical Shipping Companies. Modern Economy, 12, 401-428.

https://doi.org/10.4236/me.2021.122021

Received: January 7, 2021

Accepted: February 23, 2021

Published: February 26, 2021

Copyright $\odot 2021$ by author(s) and Scientific Research Publishing Inc. This work is licensed under the Creative Commons Attribution International License (CC BY 4.0).

http://creativecommons.org/licenses/by/4.0/

(c) (i) Open Access

\begin{abstract}
This work explained why only 31, out of about 1000 Greek-owned global shipping companies, raised from $\$ 1 \mathrm{~b}$ to $\$ 21 \mathrm{~b}$ from the international stock exchanges (mainly NYSE \& NASDAQ), since mainly 2005. First, we thought that by analyzing the advantages and disadvantages of an IPO, we could possibly provide this answer, but these found almost balanced. We drew several times on Keynes. We found that Greek shipowners consider their profession as a way of life, and they dislike the function of Stock Exchanges where a separation of ownership from management can be accomplished. Surprisingly, we found that also Stock Exchanges dislike shipping sector, mainly for its volatility! Volatility-we showed-to be a coin with two sides: one side is that earnings, NAVs, etc. are not stable, creating risk and unreliability-this side is looked-up by Stock Exchanges and banks; the other side is that of reality, because shipping sector is a cyclical one, with 8 years on average duration, providing thus-as shown-great opportunities for extremely profitable asset appreciation, which is known as "asset play"! If banks, and stock exchanges, learned-well shipping sector, they had to provide finance at rock bottom earnings, and not at high, as they do, and for a longer tenor than 4 years (to prove this we used a number of case-studies). We showed, however, the high detrimental sensitivity of banks and stock exchanges to global financial crises, like that at the end-2008. Greek-owned shipping lost 2/3 of its capitalization within 10 months, and given that crisis continued till 2020, they were unable to get finance! Finally, to avoid spreading-out a cloud of pessimism in a world under the shadow of the Pandemic, and given that shipping sector is unpre-
\end{abstract}


dictable, but well-managed, we proposed "management by visioning" based on Chaos Theory.

\section{Keywords}

Stock Exchanges \& Shipping Finance, Shipping Asset Play, Perfect IPO Timing, Future Net Asset Values-NAVs, Management by Visioning

\section{Introduction}

Economy, all along, adapted to the needs of those who produce. The $1^{\text {st }}$ was Money, terminating the inconvenience caused by exchanging goods for goods (Barter Economy). Money is useful: it is a medium of exchange, expresses prices, and accounts; it is also a store of value. Money's validity depends on trust ${ }^{1}$, and acceptance, by all (except during abnormal times). Important is that money is also a mean of building-out an investment, i.e., it is used to build a factory, to buy machinery, to hire and pay employees etc. This is an important process where monetary capital is transformed into fixed capital. We all know the importance of fixed capital.

To possess money is a necessary condition-but not a sufficient one-for starting-up a company; know-how is also needed. Keynes established, in a more correct way than the Classics, the factors, in 1936, which determine the demand for money (as well money for... speculation ${ }^{3}$ )... Thus, money has a demand as well as a supply ${ }^{4}$, and a price (=rate of interest).

Economies established also an important institution: the banks, where money from savings could be deposited, and earn also an interest ${ }^{5}$. "The interest can be defined as the amount of money one has to pay to convince its holder (lender) to depart from its possession and use for a mutually agreed time".

Banks $^{6}$ are established ${ }^{7}$ very early (c. $1700 \mathrm{AD}$ ). They attracted the majority of

\footnotetext{
${ }^{1}$ Early money expressed in coins (gold or silver, and before that, copper or iron). Later expressed in paper. Given, however, that bank notes could shake people's confidence in money, central banks backed notes with equivalent gold. Moreover, past bank notes had on their face printed a statement saying: "this note is redeemable in gold upon call at Central bank"!

${ }^{2}$ It takes also the form of money required for payments before goods produced are sold, i.e., "working capital".

${ }^{3}$ This is the demand for money for buying financial assets, influenced by income and the rate of interest.

${ }^{4}$ Central bank of a member country.

${ }^{5}$ The payment of interest caused a long wave of reactions, when first appeared, of which some were religious.

${ }^{6}$ The need of borrowing, created also "merchants of money", exchanging also foreign currency to local... Such a need was also covered by the "pawnbroker's shops". The temple of Artemis is mentioned also for storing gold or silver coins there in ancient times.

${ }^{7}$ In Greece this happened in 1841 (National Bank of Greece).

${ }^{8}$ Savings play an important role in all economies, as they release factors of production from consumption to investment. $\mathrm{St}_{-1}=\mathrm{Yt}_{-1}+\mathrm{It}\{1\}$ means that GDP equals last year's savings and today's investment. An economy in which $\mathrm{Ct}=\mathrm{Yt}\{2\}$, saves nothing, and so It $=0\{3\}$. Given that consumption $(\mathrm{Ct})$ produces nothing for future, such economy will not grow.
} 
savings $^{8}$ of people, of firms and of governments, under normal circumstances ${ }^{9}$. This was a great step forward. Moreover, bankers realized that people deposit their savings in the banks, but rarely come all at once to withdraw them, under normal circumstances. If this happens it means bankruptcy-which happened in 1929-1933. So, banks decided to keep, say ${ }^{10}$ a $12 \%$, or so, of total deposits on demand, and the rest to be lent to those qualified for. Loans are given by banks at a rate of interest higher than that paid to cash deposits so that the bank to make a profit and to cover its expenses.

Banks dominated in the finance of the Greek-owned shipping companies: in end-2006 they devoted $\$ 46 \mathrm{~b}$; in 2014, $\$ 64 \mathrm{~b}$ and, in 2015, $\$ 63 \mathrm{~b}$, three times more than those raised from Stock Exchanges-SEs in Jan. 2008 of $\$ 21$ b. Commercial banks have an advantage, vis-à-vis SEs, we reckon, by providing a personal environment, where the terms of a loan can be negotiated with company's finance manager.

Also, a shipping company may re-negotiate, with its bankers, a loan during bad times, which is very important. Banks and companies count on reciprocity, and they should be partners. The banks eventually had difficulties providing loans to enterprises at levels, which were increasing continuously for various reasons: one being inflation and the other being economies of scale.

Banking loans are related to total cash deposits ${ }^{11}$ owned by bank's customers. Important is, however, that banks pay attention also to the risk involved in bigger loans. Banks solved this, i.e., to provide big loans, by forming ${ }^{12}$ groups, and

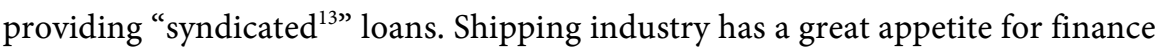
given its investment program every year, which in 2007 reached $\$ 150$ b from $\$ 25$ b in 1997 for containerships, tankers, gas and bulk carriers, and $2^{\text {nd }}$ hand ships (\$55 b; 1/3) (Stopford, 2009: p. 270). In end 2016, Greeks have ordered in the past 3 years new ships valued near $\$ 18$ billion.

Economies established Stock Exchanges. In USA, this happened in 1790 ("Philadelphia SE"), and in 1792, established the well-known NYSE, preferred by Greek-owned shipping companies along with NASDAQ ${ }^{14}$, which established in August, 1971. Unfortunately, both Banks and certain Stock Exchanges became

${ }^{9}$ If banks refuse the free withdrawal of cash deposits, or haircut them, or pay a low or negative interest or they have to apply capital controls, they definitely discourage people to use them. Banks betrayed their mission, we believe, in running after excessive profits by providing to staff extreme bonuses (2008). We have all experienced the GFC in end-2008 due to sub-prime house loans, and their securitization $\left(^{*}\right)$, given also an increased unemployment. $\left(^{*}\right)$ Securitization of assets is when a single asset-or a portfolio of assets—is divided into securities, which can be sold. This market collapsed when the people having house-mortgages-due to their unemployment-were unable to pay. ${ }^{10}$ This $12 \%$ of all deposits to be kept as cash on demand, is determined by Central Banks, which supervise banks and determine indirectly also the levels of the rates of interest.

${ }^{11}$ Banks can borrow also one from the other, and from money markets, as well from SEs.

${ }^{12}$ Banks copied, we believe, insurance companies. Insurance companies form a group with as many as possible individual insurance companies (say 15 - 20), which undertake a lower \% of the total insured amount. This splits profits, but also risk. One is leader.

${ }^{13} \mathrm{~A}$ large loan for a major project or fixed asset acquisition, which is arranged by a consortium of banks under a lead manager. This development served industry as the levels of individual shipping loans jumped from $\$ 10 \mathrm{~m}$ to $\$ 100$, after 1974 and over $\$ 200 \mathrm{~m}$ nowadays!

${ }^{14}$ Defined below. 
profit-seeking ${ }^{15}$ establishments, while we believe, for their mission, they should remain "state non-profit institutions" (as the Athens SE, established in 1876).

Today, a great part of maritime transport continues to be under depression since end-2008, as shown by the BDI (Baltic dry cargo index) (Figure 1). This index fell from almost 12,000 (11,793) units, in May, 2008, to about 500 units in Dec. 2015. Moreover, in $22^{\text {nd }}$ December, 2020, the index reached 1348 units and in 06/10/2020 2050 (source: internet). The index covers the transportation of raw materials and those for constructions, coal, grain, iron ore etc.

\section{The Aim and Structure of This Paper}

This solved, we believe, a number of issues: 1) When freight markets are high, banks "rush" to provide ${ }^{16}$ finance to shipowners, but when markets are in a recession or depression, banks stop"! This happens, though the opposite is absolutely necessary and right. 2) To trace the slow progress of Greek-owned shipping companies to raise finance, mainly since 2005, from NYSE and NASDAQ by majority, till 2018. Similarly, we traced the progress of international shipping companies since 1993. 3) We wrote-down the advantages and disadvantages of raising money from Stock Exchanges. 4) We added an important factor, which both banks and Sock exchanges ignored so far, and this is the "future net asset value"-NAV.

The paper is organized in 4 parts, as follows, after literature review: Part I deals with the advantages and disadvantages to seek finance from Stock Exchanges. Part II deals with the history of shipping companies in international stock exchanges, 1993-2018. Part III deals with shipping "asset play". Part IV deals with the possibility to obtain finance based on future $\mathrm{NAV}^{17}$. Finally, we conclude.

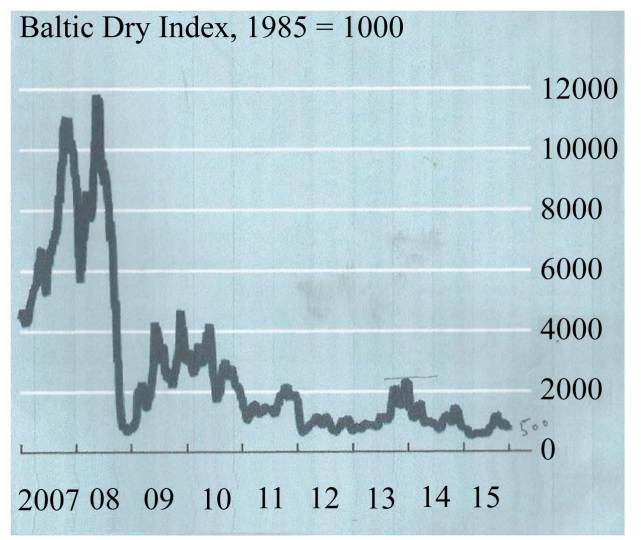

Figure 1. Baltic dry cargo index. Source: Thomson reuters.

\footnotetext{
${ }^{15} \mathrm{NASDAQ}$, since 2000 is a profit-making organization!

${ }^{16}$ Apropos is the saying: "banks give an umbrella when sun is signing, but they take it back when it is raining"!

${ }^{17}$ Suppose that a shipping company owns 10 ships valued $\$ 75 \mathrm{~m}$; also, cash \& cash equivalents of $\$ 15$ $\mathrm{m}$; accrued income of $\$ 24 \mathrm{~m}(=\$ 114 \mathrm{~m})$. Short-term liabilities $\$ 1 \mathrm{~m}$, long-term liabilities $\$ 12 \mathrm{~m}$ and accrued expenses $\$ 5 \mathrm{~m}(=\$ 18 \mathrm{~m})$. The number of shares to be issued say: $20 \mathrm{~m}$. Average NAV is $\$ 4.80$ (=\$96 m: $20 \mathrm{~m}$ ). Important is the market value of ships, consisting the big item.
} 


\section{Literature Review}

Keynes (1936: p. 150) described, without knowing them, ... the Greek shipowners! He wrote (slightly modified): ... "when enterprises were mainly owned by those who undertook them..., investment depended on a sufficient supply of individuals of sanguine temperament and constructive impulses; (they) embarked on business as a way of life, (and) did not really rely on a precise calculation of (the) prospective profit".

Stokes (1997: p. 181) mentioned: 1) Shipping Industry complained for being ignored by stock markets! 2) Stock markets considered shipping industry... risky, unpredictable and unreliable! 3) There was also a gap ${ }^{18}$ between the valuations by companies and those by $\mathrm{SEs}^{19}$ ! The real problem, we believe, is sector's cyclical behavior.

In 1997, companies listed, related to marine industry ${ }^{20}$, including shipping ones, were globally $150 ; 16$ of them ${ }^{21}$, in mid-1996, had a capitalization of $\sim \$ 31$ b. If this is compared with the New York stock markets, where capitalization was $\$ 51$ trillion, this was only $0.61 \%$ ! Thus, SEs were right to consider shipping industry negligible... 25 years ago. Moreover, shipping sector, in mid-1996, had a plethora of (under-capitalized) shipping companies till today. We estimated that the global shipping companies in 2021 are approx. 25,000 worldwide, of which only 750 are large $(3 \%)$.

Apergis and Sorros (2010) investigated the impact of earnings, coming from selling ships, on stock prices, taking 36 listed international shipping companies (2000-2008). They found that the earnings were stronger than the operating ones. They used a panel co-integration, and causality tests. They indirectly showed that shipping research is indeed poor, as from their 42 references, none referred to shipping! They took a sample of 80 listed firms in NYSE, London, Singapore, Hong Kong and Tokyo (total 3200 observations). They confirmed that income from sales of ships explains better the variations in returns.

Maritime economists know, empirically, that a good sale provides 3 years of operating net profits. These earnings, however, cannot be obtained every year, and asset play is not the core business of shipowners as presented in part III.

Drobetz et al. (2010) analyzed macroeconomic risk, and the expected stock returns, in the shipping industry (containerships-23 firms, tankers-21 and bulks-10), using monthly returns of 48 listed companies (1999-2007) and a SUR model (a seemingly unrelated regression). They concluded that shipping stocks exhibit remarkably low (stock market) betas- $\beta s^{22}$. This means that these shipping

\footnotetext{
${ }^{18}$ Shipping has specialized and reliable independent companies dealing with the evaluation of the market values of ships!

${ }^{19}$ To finance a sector, it is absolute necessary to understand it fully, in and out. Shipping sector used to show difficulties in being understood by banks and SEs. The volatility e.g., which is advanced as a bad thing, for us it is not! Volatility makes asset play possible. Also, cheap acquisitions and excellent sales are also feasible due to this! The issue is not volatility, but perfect timing!

${ }^{20}$ Maritime industry includes ports. Marine industry includes offshore industries for oil and gas and others.

${ }^{21}$ Dominant were: Carnival $\$ 8.5$ b; Mitsui $\$ 3.8$ b; Nippon $\$ 6.7$ b and P\&O $\$ 4.47$ b ( $\$ 23.5$ b) ( 76\%).

${ }^{22}$ It indicates the amount by which a stock reacts to the market.
} 
$\beta$ s are not sensitive to market moves, they dampen risk and so they are attractive to be included in a portfolio.

However, one would not expect above stock prices to rise much (Mandelbrot \& Hudson, 2006: p. 265). Authors felt the scientific need to use the "trade-weighted value of \$", "the change in G-7 industrial production" and the "oil price", so that, their cross-section of expected stock returns, to be explained. We believe that by inserting containerships into their investigation, they took the wrong message about risk as their freight rates are remarkably stable vis-à-vis tankers and dry cargo ships. They argued that there is a limited research in examining shipping stocks in an asset pricing context, though they mentioned in their reference list 10 sources out of 74 related to shipping stock returns, between 1996-2006.

Grammenos \& Marcoulis (1996) took a cross-section of shipping stock returns and reported a market $\beta<1$, among 11 shipping companies (1989-1993). Kavussanos \& Marcoulis (1997a) analyzed the market risk of shipping stocks and compared the average $\beta$ with the overall US Stock market (1985-1995); they could not relate $\beta$ to S\&P 500. Kavussanos \& Marcoulis (1997b) compared the return structure of different transport sectors and found $\beta<1$. Kavussanos \& Marcoulis (1998) stated that the systematic risk of shipping is low (1984-1995). Grammenos \& Arcoulis (2002) found negative relationships between shipping stocks and oil prices and laid-up tonnage, but not inflation and industrial production! Kavussanos et al., (2003) found a shipping stock market $\beta<1$. Kavussanos \& Marcoulis (2005) found that returns in shipping stocks are related to firm's specific and common macroeconomic factors. Gong et al. (2006) reported a $\beta<1$ in water transport.

Summarizing, it is remarkable to found-out, by almost a dozen studies reviewed above, that shipping $\beta$ s are less than 1 , and thus risk is low! This is against our experience, which says that shipping sectors, excluding containerships, are risky and volatile, as we showed this in relation to the global financial crisis in end-2008... It seems that their tools used are either not appropriate or the definition of risk is erroneous (Mandelbrot \& Hudson, 2006).

\section{Part I: The Advantages and Disadvantages for a Company to Raise Money from Stock Exchanges}

One expects great benefits from "Stock Exchanges ${ }^{23 "}$ "SEs. Keynes (1936) in his famous chapter 12, dealt with them, and explained their real function, in a different way, we believe, than most of us thought. Most of us thought that a SE is a unique place where enterprises can obtain, interest-free, the funds they need to finance a new investment by paying a dividend. A new investment is clearly directly contributing to country's economic development. Thus, a SE, is, or should be, a "temple of economic growth".

SEs, of course, have the advantage to provide higher amounts than banks, or this is what we believe, given company's past and present "net earnings" and

\footnotetext{
${ }^{23} \mathrm{An}$ auction market for buying and selling securities (stocks, shares \& bonds).
} 
"cash flow". A new investment, no doubt, creates well-founded hopes for a profit, which will bring eventually dividends to shareholders, after deducting expenses. To sell a hope for a profit, is exactly what lotteries also do!

\subsection{The Motives of Stock Buyers}

All stock-buyers do not have the same approach towards a SE, but they have 3 main and different motives, we reckon: 1) to increase their income, or pension, with money from dividends (UK). 2) To gain from selling shares when their value increases ${ }^{24}$ (USA; Greece); 3) to place savings in a SE, where a better yield, (by deducting a \% for risk), can be obtained, compared with an equivalent banking $^{25}$ deposit (Greece). Thus, buyers believe that SEs are places where everybody, and the economy, can benefit and no one can lose... Wrong!

\subsection{The Motives of the Stock Sellers}

For the listed-firms-to-be, the main motive is to obtain the funds they need, by "selling" a story, of a well thought and well prepared-investment plan, by pre-declaring a good dividend, which will be distributed in future times! Investors should not be let down, however, on their expectations, and thus firms they have to be very careful in calculating dividends, before announced. Shareholders-investors have an elephantine memory.

\subsection{The Main Advantages or Disadvantages of Being Listed}

The most crucial fact for listed companies is that the current value of their shares varies from their past one. And here starts the problem for Greek shipowners! A SE determines the value of a company's share, minute by minute, and whatever future glory does not count!

We believe that the laws of demand and supply work in SEs, but the moving forces behind them may, regretfully, be non-economic ${ }^{26}$. Keynes wrote about mass psychology. This may not be bad, one may say, but one must investigate the reasons that mobilized a stock's demand or supply! If these are psychological, people at large, and economists, in particular, cannot understand!

Nowadays, one speaks of fake and pre-fabricated news in social media. Investors have to distinguish fake news from real ones like: a fall in seaborne trade for shipping industry, e.g., which will cause a fall in shipping demand, will bring a ${ }^{24}$ SEs usually "prefer" companies to have an IPO at as low price as possible, and investors to buy these stocks "expecting" an increase during aftermarket! So, SEs provide a motive to investors at the expense of listed companies. Most of the times, however, the stock price falls in the next day of IPO! ${ }^{25}$ After Global Financial Crisis-GFC in end-2008, interest rates fell and, in some "safer" countries, they were negative. This coupled with capital controls, and with the fact that authorities in certain countries used people's deposits to diminish banks' losses. These developments led people to SEs, and especially to hoard.

${ }^{26}$ When the Greek coastal shipping entered into Athens SE in 1994, for the first time, a company out of its fear that EU coastal shipping firms will rush into Aegean and Ionian Sea, and buy all ships, following the cabotage waive in 2003, this good company offered shares, and its name-already listed-to a number of other coastal firms owning about 25 ships. Its manager, who committed suicide sometime after, did not realize that a marine accident which occurred in one of the above 25 ships, could cause a substantial fall in the price of mother company's stock (Goulielmos et al., 2009)! 
fall in stock prices of listed shipping companies, as profits are expected to be reduced. This is what happened in end-2008. Thus, SEs estimate the present impact of future developments.

More important consequence than that of fake news is that any substantial fall in the price of a share, invites potential buyers, who wish to take-over other companies, cheaply, especially if they were profitable in the past ${ }^{27} \ldots$

One may put the above issue in a shipping context: suppose a shipping firm wishes to build 4 ships, and asks a shipyard for prices; the shipyard says that this is $\$ 100 \mathrm{~m}$ each, for delivery in 2 years (cost $=\$ 400 \mathrm{~m}$ ). The interested buyer looks in SEs, and finds a shipping company having 4 such ships, running, profitable and young! The price of the shares of these 4 used ships is such that each ship is valued, by SE, at $\$ 50 \mathrm{~m}$ each (cost $=\$ 200 \mathrm{~m})$... The decision is obvious.

\subsection{A SE Separates Management from Ownership}

Another important function -especially for Greek shipowners-of a SE is that it can separate management from ownership, something which occurred since 1930s, due to the fact that firms became very large from small and family ones. There are also investors that wish to benefit from the profits of a company, without involvement in management. Then, professional managers take-over management, who know perhaps better. This service is also offered in shipping by what we call "third party shipping managers" (Goulielmos et al., 2011).

In Greek shipping, managers and owners are the same persons, as the shipping profession is a way of life for Greeks, as mentioned also by Keynes in another context. The motives of these two types of managers-professionals and owners-are quite different. We will not elaborate this important issue here.

\subsection{Malfunctions in SEs}

There are also certain malfunctions in SEs. People became rich by having inside information about a stock, though this is not permitted. Some became also rich by buying and selling shares of their own company, which is permitted ${ }^{28}$. We saw also hundreds of ordinary people to lose their savings (1999 in Athens SE bubble; \& in 1929-1933), which was unfair for small savers.

We next summarize the main advantages and disadvantages of SEs (Table 1).

As shown, the disadvantages and the advantages are almost balanced!

\section{The History of Shipping Companies in Global Stock Exchanges, 1993-2018}

1) $1993-2002$

\footnotetext{
${ }^{27}$ Certain companies watch other companies to see the course of their stock price as well their yearly profits, and they buy-over their stock! This in USA is a practice to boost profits, and satisfy shareholders, in companies having low, but steady, returns for some years...

${ }^{28}$ Suppose a company bought $1 \mathrm{~m}$ shares out of say $14 \mathrm{~m}$ from its initial public offer-IPO, say at $\$ 10$ each. After sometime the price of the share goes-up to $\$ 11$. The company sells them and gains $\$ 1$ $\mathrm{m} .$. When stock falls say by $1 \$$, company buys $1 \mathrm{~m}$ shares, and so on. A company said that its $1 / 2$ yearly profits came from its production and $1 / 2$ from company's stock transactions.
} 
Table 1. Main advantages and disadvantages for a company to be listed.

\begin{tabular}{|c|c|c|c|}
\hline Advantages & Advantages & Disadvantage & Disadvantage \\
\hline $\begin{array}{l}\text { SEs provide to business firms the } \\
\text { required funds, interest-free, \& } \\
\text { publicly, for an investment } \\
\text { well-planned ( } \& \text { marketed), given its } \\
\text { NAV \& a steady promised dividend } \\
\text { in a \% above banking interest plus } \\
\text { a \% for the risk }\end{array}$ & $\begin{array}{l}\text { Get rid of a past } \\
\text { investment \& become } \\
\text { liquid }\end{array}$ & $\begin{array}{l}\text { Become vulnerable to be taken-over by } \\
\text { another company, if the price of stock } \\
\text { falls substantially \& company used to be } \\
\text { profitable; this is not liked by Greek } \\
\text { companies, which run a business as a } \\
\text { way of life; potential loss of } \\
\text { management }\end{array}$ & $\begin{array}{l}\text { A firm may fail to pay the } \\
\text { dividend promised; or it fails } \\
\text { to carry-out the investment } \\
\text { stated; or the "raised money" } \\
\text { goes for purposes other than } \\
\text { those stated... etc. }\end{array}$ \\
\hline $\begin{array}{l}\text { SEs encourage new investments with } \\
\text { other people's money-no need one to } \\
\text { risk own money }\end{array}$ & $\begin{array}{l}\text { Own shares bought by } \\
\text { the company may be } \\
\text { sold for profit, if stock } \\
\text { price goes up in the } \\
\text { aftermarket and so on }\end{array}$ & $\begin{array}{l}\text { Listing causes costs: } \\
-\quad \text { for listing } \\
-\quad \text { for internal auditors } \\
-\quad \text { for a perfect } \\
\text { accounting \& for frequent reporting } \\
\text { (rise in administration cost) }\left({ }^{*}\right) \text {; ability } \\
\text { to obey to all SE rules \& obligations }\end{array}$ & losing savings \\
\hline $\begin{array}{l}\text { Dividends reinforce a pension, or } \\
\text { income; the selling stock high \& } \\
\text { buying it low, provides a profit }\end{array}$ & Transparency is required & $\begin{array}{l}\text { Inside information about company's } \\
\text { share may be used, though illegal }\end{array}$ & $\begin{array}{l}\text { SE evaluates the value of a } \\
\text { company each minute, no } \\
\text { matter its past or its future } \\
\text { glory }\end{array}$ \\
\hline $\begin{array}{l}\text { SE may have a saying in who is } \\
\text { company's CEO ("Stelmar" case)! }\end{array}$ & $\begin{array}{l}\text { SEs (NYSE) does not } \\
\text { allow a stock price to fall } \\
\text { below } \$ 1 \& \text { thus } \\
\text { demands a counter } \\
\text { action within a month }\end{array}$ & $\begin{array}{l}\text { Speculation }{ }^{29} \text { on company's share price } \\
\text { is open }\end{array}$ & $\begin{array}{l}\text { Stock prices are influenced by } \\
\text { a variety of reasons, including } \\
\text { fake news }^{30}\end{array}$ \\
\hline $\begin{array}{l}\text { Keep a proper \% of company's stock } \\
\text { so that to forbid take-overs (Greek } \\
\text { shipowners) }\end{array}$ & $\begin{array}{l}\text { Some shareholders are } \\
\text { benefitted if their } \\
\text { company is sold at a } \\
\text { level higher than its } \\
\text { current stock value } \\
\text { ("Stelmar" case), unlike } \\
\text { the owners }\end{array}$ & $\begin{array}{l}\text { Speculators }{ }^{31} \text { are present } \& \text { their } \\
\text { purposes }\left(^{* *}\right) \text { are different than those of } \\
\text { the companies }\end{array}$ & $\begin{array}{l}\text { Company's decisions cannot } \\
\text { be fast and independent, as } \\
\text { shipping needs }\end{array}$ \\
\hline $\begin{array}{l}\text { Repay expensive loans with cheap } \\
\text { money from SE }\end{array}$ & & $\begin{array}{l}\text { If a company intends to be sold, then } \\
\text { board of directors promised to be } \\
\text { retained in their posts, after taking-over, } \\
\text { vote in favor of it ("Stelmar" case) }\end{array}$ & $\begin{array}{l}\text { Shareholders (investors) are } \\
\text { partners }\end{array}$ \\
\hline
\end{tabular}

Source: author; $\left(^{*}\right)$ Hellenic C. de-listed for this reason; ${ }^{* *}$ Keynes (1936: p. 158) argued that "speculation is the activity dealing with forecasting market psychology".

Stock exchanges were disappointed, as mentioned, by shipping's volatility, which characterizes shipping companies till this day. We chose one company to show this (Figure 2) in relation to its "return on capital".

As shown, this company had a positive return on capital, $8 \%$, but only in 1991 ; after 1991, returns were below $1.1 \%$ or negative, till 1995. Surely, these levels could not satisfy any SE.

\footnotetext{
29"Buy cheap; sell dear".

${ }^{30}$ One may not believe it, but the election of President Trump, in Nov.2016, boosted up stock prices of Greek listed shipowners in Wall and NASDAQ, like those of Dryships from $\$ 4.6 /$ per stock to $\$ 102$ and finally to $\$ 9$; Diana from $\$ 2.49$ to $\$ 5$ and finally to $\$ 3.4$; StealthGas from $\$ 2.71$ to $\$ 4.15$ and finally to $\$ 3.65$ !

${ }^{31}$ They try to anticipate forthcoming stock prices and profit from them by buying or selling them.
} 


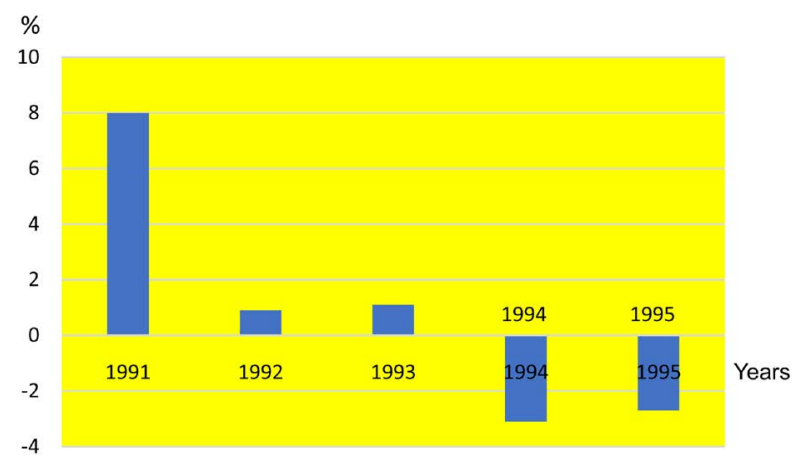

Figure 2. OMI Corporation (tankers), return on capital, 1991-1995, \%. Source: Data from Stokes (1997: p. 186).

Let us see now the 8 major listed international shipping companies in 1993 (Table 2).

As shown, 8 shipping companies raised $\$ 822 \mathrm{~m}$ in 1993 (average: $\$ 103 \mathrm{~m}$ ). Certain of the above shipping companies-called the "new wave of shipping IPOs"-were sound, having well-structured propositions, suitable to produce a rather serious performance in the aftermarket, and possessing also a rather long track record, despite the poor etc. performance in the aftermarket of $50 \%$ of them.

In mid-1996, 16 shipping companies listed internationally, capitalized at $\$ 31 \mathrm{~b}$ (almost 4 times up since 1993) (average rose to $\$ 1.94$ b). In 1998, 262 shipping firms listed in international stock exchanges, of which 8 were Greek $(3 \%)^{32}$. Of these 8, three issued "high yield shipping bonds"-HYB: "Eletson Holdings"; "Ermis Mar."; "Pegasus Shipping".

The remaining 5 were: "Anangel American Shipholdings" (ocean going); "Attica Enterprises" (coastal); "Lesvos Maritime Co" (coastal); "Royal Olympic

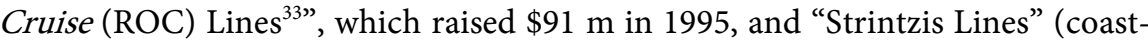
al; listed also in 1994 in "Athens Stock Exchange").

"Anangel", established by Antonis Angelicousis was the first ${ }^{34}$ to be listed in NYSE in 1996. In 2002, "Tsakos Energy Navigation" (March 5th) listed also in NYSE, raising \$ 109 m (7.35 m shares), in order to build ships, and repay bank loans, while in 2001 "Stelmar" has been listed.

\section{2) 2005-2007}

In the $1^{\text {st }}$ half of 2005, 5 Greek shipping companies listed in London and New York and this was their $1^{\text {st }}$ time (Table 3 ).

As shown, 5 Greek shipping companies raised $\$ \sim 1.02$ b in early 2005 (\$204 m on average). These were helped by the increase in their profits in 2005. Their

\footnotetext{
${ }^{32}$ Data from "TradeWinds" journal.

${ }^{33} \mathrm{~A}$ traditional Greek passenger shipping company offering cruises in Great Lakes, owned by "Potamianos" family ("Epirotiki"), since before $2^{\text {nd }}$ World War. Merged with Sun Line (Greek) and Louis Cruise Lines (Cypriot). In 2001 had a \$ 129 m sales with 8 cruising ships. Worth mentioning is that due to "Kosovo War", ROC's value of shares fell from \$15 to \$2 each!

${ }^{34}$ It is also argued that "Anangel" adopted the policy to provide an average fixed $\%$ of dividend per year per $\$ 100$ value of shares.
} 
Table 2. The "New wave" of shipping IPOs, 1993.

\begin{tabular}{|c|c|c|c|c|c|}
\hline $\begin{array}{l}\text { Company, } \\
\text { Year established, type }\end{array}$ & Market focus & $\begin{array}{l}\text { Year of IPO, } \\
\text { price per share }\end{array}$ & $\begin{array}{l}\text { Amount raised/ } \\
\text { Stock Exchange }\end{array}$ & Performance & Remarks \\
\hline $\begin{array}{l}\text { "Smedvic", 1993, } \\
\text { family company }\end{array}$ & Medium tankers & 1993 July, \$10 & $\$ 129$ m/Oslo & $\begin{array}{l}\text { Negative } \\
1993-1995\end{array}$ & $\begin{array}{c}\text { Taken-over by Bona, } \\
\text { at } \$ 8 / \text { stock }\end{array}$ \\
\hline " $1^{\text {st }}$ Olsen", 1993 , asset fund & Suezmax & 1993 Oct., $\$ 10$ & $\$ 200$ m/Oslo & Low & 1997 Jan. $=\$ 8.77$ \\
\hline $\begin{array}{l}\text { "Bona Sh. Ltd.", 1990, } \\
\text { tanker ownership of } \\
\text { "Leif Hoegh \& Co. AS" }\end{array}$ & $\begin{array}{c}\text { Medium } \\
\text { tankers \& OBO }\end{array}$ & 1993 Dec., \$9 & $\$ 106$ m/Oslo & Improving & $1997=\$ 13.07$ \\
\hline $\begin{array}{l}\text { "Western Bulk", 1991, pool } \\
\text { company }\end{array}$ & $\begin{array}{l}\text { Handy BC } \\
\text { Handymax }\end{array}$ & 1993 Oct., $\$ 7.14$ & $\$ 42 \mathrm{~m} /$ Oslo & Poor & Fall 30\% \\
\hline “London \& Overseas”, 1948 & Medium tankers & \$15, Nov., 1993 & $\$ 75$ m/NY, Lon. & Steady & Fall 5\%; $\$ 14.25$ \\
\hline “Pacific Basin”, 1987 + CMB & Handy bulk c. & Sept. 1994, \$14 & $\$ 73 \mathrm{~m} / \mathrm{NY}$ & As expected & $\begin{array}{c}\$ 16.22, \text { taken } \\
\text { over in } 1996\end{array}$ \\
\hline $\begin{array}{l}\text { “Teekay Corp.”, 1973, } \\
\text { est. by Torben Karlshoej }\end{array}$ & Aframax & 1995 July, \$21.5 & $\$ 138 \mathrm{~m} / \mathrm{NY}$ & Satisfactory & $\$ 27.275$ in 1997 \\
\hline \multirow[t]{2}{*}{$\begin{array}{c}\text { "Nordic Am. Tank. Sh. Ltd.", } \\
\text { 1995, special purpose }\end{array}$} & Suezmax tankers & $\begin{array}{l}1995 \text { Sep., } \$ 5 / \text { warrant; } \\
1977 \text { at } \$ 10.21\end{array}$ & $\$ 58.7 \mathrm{~m}$ & Poor & Warrant at $\$ 3.75$ \\
\hline & & Total 8 companiesà & $\$ \sim 822 \mathrm{~m}$ & & \\
\hline
\end{tabular}

Source: Data from Stokes (1997: pp. 187-193).

Table 3. The 5 Greek shipping firms listed, for their first time, during $1^{\text {st }}$ half of 2005 , in Lon. SE \& NYSE.

\begin{tabular}{|c|c|c|c|c|}
\hline $\begin{array}{l}\text { Company/Year } \\
\text { of IPO (2005) }\end{array}$ & \multicolumn{2}{|c|}{$\begin{array}{c}\text { Amount } \\
\text { raised } \mathrm{m} \$ \%\end{array}$} & $\begin{array}{c}\text { Stock } \\
\text { exchange }\end{array}$ & Remarks; profits; fleet \\
\hline "DryShips Inc." & $\sim 269$ & 26 & Nasdaq $^{35}$ & $\begin{array}{l}2 \text { Profits 2004: } \$ \sim 39 \mathrm{~m} ; 2005: \$ \sim 111 \mathrm{~m} \text {; } \\
\text { Ships: 27; } 2.32 \mathrm{~m} \text { dwt. }\end{array}$ \\
\hline $\begin{array}{l}\text { "Diana }{ }^{36}\left({ }^{*}\right) \\
\text { Shipping Co." }\end{array}$ & $\sim 242$ & 24 & NYSE & $\begin{array}{l}\text { Profits: } \$ \sim 60 \mathrm{~m} \mathrm{2004;} 2005: \$ 65 \mathrm{~m} \text {; } \\
12 \text { ships } 1.065 \mathrm{~m} \mathrm{dwt}\end{array}$ \\
\hline $\begin{array}{l}\text { "Quintana } \\
\text { Maritime Ltd." }\end{array}$ & $\sim 221$ & 22 & Nasdaq & $\begin{array}{l}\text { Profits } \$ 5.5 \mathrm{~m} \text { 2005; } 10 \text { ships, } 0.92 \mathrm{~m} \mathrm{dwt} \text {; } \\
\text { it took-over "Metrostar" (owning } 17 \text { ships); }\end{array}$ \\
\hline $\begin{array}{l}\text { "Aries } \\
\text { Maritime Passport" }\end{array}$ & 170.5 & 17 & Nasdaq & $\begin{array}{l}\text { Profits } \$ \sim 15 \mathrm{~m} \text {; } 9 \text { tankers; } 5 \text { containerships; } \\
\text { it took-over "Magnus Carriers" }\end{array}$ \\
\hline $\begin{array}{c}\text { "StealthGas Inc." } \\
(06 / 10 / 05)\end{array}$ & 116 & 11 & Nasdaq & Profits $\$ \sim 12 \mathrm{~m}$ (2005); 27 LPG \\
\hline Total 5 & $\$ \sim 1.02$ & $00 \%$ & $\begin{array}{l}\text { Average } \\
\$ 204 \mathrm{~m}\end{array}$ & "Stelmar" taken-over by OSG \\
\hline
\end{tabular}

Source: Companies' sites and press releases.

IPOs-almost 1 per week-motivated additional 11 companies. But this was an oversupply! Eight of these 11 companies raised about $\$ \sim 1.39 \mathrm{~b}$ (174 $\mathrm{m}$ on average). There was obviously no coordination among Greek companies over IPO’s

${ }^{35}$ National Association of Securities Dealers Automated Quotation system, having over 4000 companies in USA over-the-counter in end-1985, $3^{\text {rd }}$ worldwide after NY and Tokyo (Gilpin, 1986).

${ }^{36}$ NYSE selected by "Diana" for providing higher liquidity and a better policy towards long run strategies. 
timing as this is classical for all matters (Table 4).

As shown, in the $2^{\text {nd }}$ half of 2005, 3 Greek shipping companies postponed their IPO due to the probability to face a weak demand due to oversupply of IPOs and a fall in freight rates.

Let us see now 2006 (Table 5).

As shown, 10 companies were listed in 2006, double of that of 2005. In 2004 almost \$106 m less profits derived (except for “General Maritime”). During 2006, 3 companies are recorded in addition to 14: “TEN"; “Top Tankers"; and “Genmar”, which raised $\$ 237 \mathrm{~m}$.

Table 4. Greek shipping companies' listings in $2^{\text {nd }}$ half of 2005.

\begin{tabular}{|c|c|c|c|}
\hline $\begin{array}{c}\text { Company/Year } \\
\text { of IPO }\left(20052^{\text {nd }} \text { half }\right)\end{array}$ & $\begin{array}{c}\text { Amount } \\
\text { raised } \mathrm{m} \$ \%\end{array}$ & $\begin{array}{c}\text { Stock } \\
\text { exchange }\end{array}$ & Remarks; fleet; profits \\
\hline "Freeseas" & NA & & \\
\hline "Star Mar." & 189 & Amex & \\
\hline "Navios"37 & NA & & \\
\hline "Euroseas" & NA & & $\begin{array}{l}\text { Bought "Cove Apparel" } \\
\text { (without a specific mission) } \\
\text { for an unexpensive listing! }\end{array}$ \\
\hline “Excel" & 124 & NYSE & $\begin{array}{l}\text { 2004; raised } \$ 55 \mathrm{~m} \\
\text { also from Amex }\end{array}$ \\
\hline "Genco" & 287 & & $\begin{array}{l}\text { Plus, the companies: General; } \\
\text { Gonmar; Genco Sh. \& Trading, } \\
\text { listed } 22 / 07 / 2005 \text { for } 11.3 \mathrm{~m} \text { shares } \\
\text { at } \$ 22-\$ 23 \text {; placed } 11.8 \mathrm{~m} \\
\text { at } \$ 21=\$ 247.5 \mathrm{~m} \text {; stock price: } \\
\quad \$ 20.87 \text { at the } 1^{\text {st }} \text { day }\end{array}$ \\
\hline $\begin{array}{c}\text { "Global Oceanic } \\
\text { Carriers" }\end{array}$ & 41 & Lon. SI & \\
\hline "Goldenport Hold.s" & 105 & Lon. & \\
\hline "Omega" & $\begin{array}{l}204 \\
240\end{array}$ & $\begin{array}{l}\text { NASDAQ } \\
\text { Singapore }\end{array}$ & Two SEs have been used \\
\hline $\begin{array}{c}\text { “Aries” } \\
\text { (plus control of } \\
\text { "Magnus Carriers" } \\
\text { \& Aries Energy) }\end{array}$ & NA & NYSE & $\begin{array}{l}\text { Obliged to reduce the number of } \\
\text { shares and IPO's price }<\$ 14-\$ 16 \text {; } \\
\text { achieved } \$ 12.5 \text { during } 1^{\text {st }} \text { day; } \\
\text { in July } 2005 \text { valued at } \$ 14.85 ; \\
\text { company's executive manager } \\
\text { accused for criminal action }\end{array}$ \\
\hline $\begin{array}{l}\text { “Capital Sh. Management” } \\
\text { (“Capital Mar. \& Trading”) } \\
\text { controlling also “Barclay Sh.” }\end{array}$ & 250 intended & & Postponed \\
\hline "StealthGas" & NA & NASDAQ & Postponed \\
\hline "Golden Energy Marine" & $\begin{array}{l}230 \text { intended } \\
200 \text { raised }\end{array}$ & & $\begin{array}{l}\text { Postponed for } 8 \mathrm{~m} \\
\text { shares at } \$ 24-\$ 27\end{array}$ \\
\hline Total $8 \rightarrow$ & $\$ 1.39 \mathrm{~b}$ & & \\
\hline
\end{tabular}

Source: As in previous table.

37“Navios” was bought by “ISE” against $\$ 607.5 \mathrm{~m}$ of which $\$ 520 \mathrm{~m}$ derived from a loan. 
Table 5. 10 Greek listed companies in 2006 (end) and their capitalization.

\begin{tabular}{|c|c|c|}
\hline $\begin{array}{c}\text { Company/ } \\
\text { Year of IPOs: } 2006\end{array}$ & $\begin{array}{c}\text { Stock } \\
\text { Exchange }\end{array}$ & Remarks; fleet; profits \\
\hline "Euroseas" & NY & Profits $\$ 25 \mathrm{~m} ; 8$ ships \\
\hline "Excel" Maritime & NY & Profits $\$ 32 \mathrm{~m} 2004 ; \$ \sim 68 \mathrm{~m} \mathrm{2005;} 17$ ships \\
\hline "Freeseas" & NASDAQ & $\begin{array}{l}\text { Profits } \$ 0.1 \mathrm{~m} \text {; merged with } \\
\text { "Trinity Partners Acquisition" }\end{array}$ \\
\hline "Genco" Shipping & NASDAQ & 17 ships; profits $2005 \$ 54.5 \mathrm{~m}$ \\
\hline "General" Maritime & NY & Profits $\$ 315$ in 2004; $\$ 212 \mathrm{~m}$ in 2005 \\
\hline "Goldenport Holdings" & LSE & $\begin{array}{l}9 \text { dry cargo; } 8 \text { container ships; } \\
\text { profits } \sim 30 \text { m 2004; } \$ 45 \text { m (2005) }\end{array}$ \\
\hline "Navios" Maritime & NASDAQ & \\
\hline "Omega" Navigation & NASDAQ & 2 ships \\
\hline "Top Tankers" & NASDAQ & $\begin{array}{l}\text { Profits } \$ 33 \mathrm{~m}(2004) ; \$ 69 \mathrm{~m}(2005) \text {; } \\
\qquad 27 \text { tankers; } 2.6 \mathrm{~m} \mathrm{dwt}\end{array}$ \\
\hline “Tsakos Energy Navigation” & NY & $\begin{array}{l}\text { Profits } \$ 143 \mathrm{~m}(2004) ; \$ 162 \mathrm{~m}(2005) ; \\
\qquad 51 \text { tankers; } 5.1 \mathrm{~m} \mathrm{dwt}\end{array}$ \\
\hline Total 10 companies & & \\
\hline
\end{tabular}

Source: As in previous Table.

In end-2006, the global listed shipping companies were 202, and the companies in HYB increased to 31, which means that investors were after a higher risk and yield than hitherto. No Greek company appeared in HYB this time. Greeks in 2006 reached 20 listed shipping companies starting from 10 (Table 6), with a total of $\$ 11$ b capitalization, i.e., 10 times more than that of 2005 , within one year!

As shown, "General" is the protagonist with $\sim 22 \%$ share in total capitalization. The average capitalization $(\$ 550 \mathrm{~m})$ had a substantial rise since $\$ 174 \mathrm{~m}$ and $204 \mathrm{~m}$ in 2005.

In 2007 (July), 12 more companies recorded (+), while 4 were missing (Euronav; Genco; General and ROC) (Table 7).

As shown, 28 shipping companies raised $\$ 15.3 \mathrm{~b}$ in 2007, against $\$ 11 \mathrm{~b}$ in 2006 by 20 companies: $+39 \%$ ) (average $\$ 546 \mathrm{~m}$ ). The protagonist this time was "Danaos" with $\sim 11 \%$ total capitalization. As shown, the Greek-owned shipping gradually listed in international SEs, and this, we believe, will continue, as soon as Pandemic passes away and freight rates improve.

3) The end-2008 impact on the capitalization of Greek-owned shipping companies

This part is very important. In end-2008, the Greek listed companies recorded were 25 (Table 8).

As shown, tankers in Jan. 2008, had a smaller share in capitalization: $\sim 18 \%$; dry cargoes $\sim 68 \%$ and the diversified ones-including containerships-13.5\%. Dry cargo ships were dominant in SEs, as less dangerous, we believe, vis-à-vis 
Table 6. 20 Greek listed companies in 2006 and their capitalization.

\begin{tabular}{|c|c|c|c|c|c|}
\hline \multirow{2}{*}{ Company (sector) } & \multicolumn{2}{|c|}{ Capitalization } & \multirow{2}{*}{ Company (sector) } & \multicolumn{2}{|c|}{ Capitalization } \\
\hline & $\$ \mathrm{~m}$ & $\%$ & & $\$ \mathrm{~m}$ & $\%$ \\
\hline “Anek lines" (coastal) & 121 & - & "Goldenport" & 330 & 3 \\
\hline "Aries Mar." & 284 & - & “Mar. Co of Lesvos" (coastal) & 144 & - \\
\hline "Attica Holdings" (coastal) & 555 & 5 & "Minoan Lines" (coastal) & 384 & $\sim 4$ \\
\hline "Blue Star Mar." (coastal) & 444 & 4 & "Navios Mar." & 339 & 3 \\
\hline "Diana sh." & 840 & 8 & "Quintana" & 515 & 5 \\
\hline "Dryships" & 413 & 4 & "Royal Olympic Cruise Lines" & 0 & - \\
\hline "Euronav" & 1736 & 16.5 & "Stealthgas" & 176 & - \\
\hline "Excel" & 266 & - & “Top tankers" & 167 & - \\
\hline "Genco" & 655 & 6 & “Tsakos En.” & 842 & 8 \\
\hline \multirow[t]{3}{*}{ "General" } & 2296 & 22 & "Freeseas" & 46 & - \\
\hline & & & Total $20 \rightarrow$ & \multicolumn{2}{|c|}{$\$ 11 b\{\$ 10.55 b) ;$} \\
\hline & & & & \multicolumn{2}{|c|}{ Average $\$ 550 \mathrm{~m}$} \\
\hline
\end{tabular}

Source: Companies' sites and announcements.

Table 7. Greek-owned shipping companies listed in July 2007.

\begin{tabular}{|c|c|c|c|c|c|}
\hline Company & Cap. $\$ \mathrm{~m} / \mathrm{SE} /$ & $\%$ & Company & Cap. $\$ \mathrm{~m} / \mathrm{SE} /$ & $\%$ \\
\hline "Aries" & $260\left(^{*}\right)$ & & “Top tankers" $\left.{ }^{\star}\right)$ & 233 & \\
\hline "Danaos" + & $1651(* *)$ & 11 & “Tsakos E N" (**) & 1300 & 8.5 \\
\hline "Diana" & $1351(* *)$ & 9 & "Freeseas" $\left(^{*}\right)$ & 46 & \\
\hline "DryShips" & $1390\left(^{*}\right)$ & 9 & "Paragon" Private 144A + & 70 & \\
\hline "Excel" & $459\left(^{*}\right)$ & & “Aegean" $\left(^{* *}\right)+$ & 769 & \\
\hline "Navios" & $1067(* *)$ & & "Ocean freight" $\left(^{* *}\right)+$ & 251 & \\
\hline "Omega" + & $324\left(^{*}\right)(* * *)$ & & “Goldenport” Lon. & 501 & \\
\hline "Quintana" & $857(*)$ & & “Global Ocean. Carr.” AIM + & 84 & \\
\hline "Star Mar. Acq." + & 346 Amex & & "Globus" (AIM) + & 169.6 & \\
\hline "StealthGas" & $257\left(^{*}\right)$ & & "Capital" $\left({ }^{*}\right)+$ & 625 & \\
\hline "Euroseas" + & $260 \mathrm{OTCBB}^{38}$ & & "Oceanaut" AMEX + & 196 & \\
\hline "Anek" & 560 Athens & & "Attica" Athens & 798 & \\
\hline "Blue Star ferries" & 559 Athens & & "Lesvos" Athens & 175 & \\
\hline \multirow[t]{2}{*}{ "Minoan" } & 574 Athens & & "Ocean Tankers" Cyprus + & 143.4 & \\
\hline & & & Total $28 \rightarrow$ & $\$ 15.3 \mathrm{~b}$ & (\$15.28 b) \\
\hline
\end{tabular}

$\left.{ }^{*}\right)$ Nasdaq; $\left({ }^{* *}\right)$ Nyse; $(* *)$ Singapore.

${ }^{38}$ Not listed in stock exchanges-over the counter market rated BB. 
Table 8. The capitalization of 25 Greek shipping companies under global financial crisis, between Jan. $2^{\text {nd }}, 2008-$ Nov. $7^{\text {th }}, 2008$.

\begin{tabular}{|c|c|c|c|c|c|c|c|}
\hline $\begin{array}{l}\text { Company/ } \\
\text { sector }\end{array}$ & $\begin{array}{l}\text { Capitalization } \\
\text { Jan. } 2^{\text {nd }} \\
2008 \$ \mathrm{~m} \\
\text { (rounded) }\end{array}$ & $\begin{array}{l}\text { Capitalization } \\
\text { Nov. } 7^{\text {th }} \\
2008 \$ \mathrm{~m} \\
\text { (rounded) }\end{array}$ & $\begin{array}{l}\text { Fall \%, } \\
\text { rounded }\end{array}$ & $\begin{array}{l}\text { Company/ } \\
\text { sector }\end{array}$ & $\begin{array}{l}\text { Capitalization } \\
\text { Jan. } 2^{\text {nd }}, 2008 \$ \mathrm{~m} \text {, } \\
\text { rounded }\end{array}$ & $\begin{array}{l}\text { Capitalization } \\
\text { Nov. } 7^{\text {th }} \\
2008 \$ \mathrm{~m}\end{array}$ & $\begin{array}{l}\text { Fall \%, } \\
\text { rounded }\end{array}$ \\
\hline "Aegean" (1) & 1649 & 467 & 72 & "Freeseas" (2) & 126 & 45 & 64 \\
\hline “Capital Pr." (1) & 227 & 109 & 52 & “Navios H” (2) & 1262 & 227 & 86 \\
\hline “Omega” (1) & 240 & 110 & 54 & “Oceanaut” (2) & 192 & 189 & 2 \\
\hline “TEN” (1) & 1414 & 905 & 36 & “Paragon" (2) & 496 & 153 & 69 \\
\hline “Top Ships” (1) & 69 & 34 & 51 & "Safe B." (2) & - & 381 & - \\
\hline "Ocean tankers" & 188 & 112 & 40 & "Seanergy" (2) & 304 & 163 & 46 \\
\hline "Diana" (2) (**) & 2311 & 1074 & * & & & & \\
\hline "Dryships" $(2)^{* *}$ ) & 4919 & 869 & $* * *$ & "Globus" (2) & 303 & 49 & 84 \\
\hline “Eagle" (2) & 1237 & 460 & 63 & "Hellenic C" (2) & 199 & 61 & 69 \\
\hline “Eurosea"s (2) & 383 & 155 & 59 & “StealthGas"-LPGs & 304 & 136 & 54 \\
\hline “Star B C” (2) & 702 & 216 & 69 & $\begin{array}{l}\text { "Goldenport H”-dry } \\
\text { cargo-containers }\end{array}$ & 572 & 102 & 82 \\
\hline "Excel” (2) & 1708 & 461 & 73 & $\begin{array}{l}\text { “Aries"-tankers } \\
\text {-containers }\end{array}$ & 191 & 26 & 86 \\
\hline \multirow[t]{2}{*}{ "Danaos"-containers } & 1452 & 435 & 70 & $\begin{array}{c}\text { "Oceanfreight" } \\
\text { tankers-dry cargoes }\left({ }^{* *}\right)\end{array}$ & 279 & 84 & 70 \\
\hline & & & & Total 25; & $\begin{array}{c}\$ \sim 21 \mathrm{~b} \\
\text { Average } \$ 840 \mathrm{~m}\end{array}$ & $\begin{array}{c}\$ \sim 7 \mathrm{~b} \\
\text { Average } \$ 280 \mathrm{~m}\end{array}$ & $2 / 3$ less! \\
\hline
\end{tabular}

Source: Data from Xiradakis G. in "Naftika Chronika" journal, 2009, pp. 24-27; notes: (1) tankers; (2) dry cargo; $\left(^{*}\right) 53.5 \%$ fall; (**) able to raise funds from SE despite general decadence! $\left.{ }^{* * *}\right) 6$ times.

tankers. In Nov. 2008, tankers had a cap. of $\sim 25 \%$, dry cargoes $64 \%$ and the rest $11 \%$. Average capitalization fell from $\$ 840 \mathrm{~m}$ to $\$ 280 \mathrm{~m}$.

Important is to stress the impact, on capitalization of the stocks of 25 Greek shipping companies, of the GFC, which was substantial! Their total value, fell, in Nov. 2008, to its 1/3 level of what used to be in 2008 Jan. (within 10 months)! How on earth a shipowner can trust SEs after the end-2008 crisis?

4) The further impacts of end-2008 crisis

Equal important-to the lost capitalization-we believe-is the fact that the listed companies were unable, by majority, to find finance, either from SEs or from banks, during last crisis! This justifies our proposal addressed to shipping companies to maintain a "crisis reserve", so that to be liquid in times of crisis, retaining profits from good past years.

However, the above proposal may require up to $\$ 538 \mathrm{~m}$ for each company on average, using end-2008 data! This means, assuming an average profit of $\$ 70 \mathrm{~m}$ per year per listed company, (estimated from data above), or about 8-yearly profits. Companies with over $\$ 180 \mathrm{~m}$ p.a. profits, however, may cover the above 
amount with only 3-yearly profits... Another way to support one's value of shares, is of course to buy company's own shares (based on law of demand). But even this, requires liquidity.

5) 2016

In early 2016, (May), 40 Greek companies were recorded in SEs: 2 were ports (Piraeus; Thesaloniki); 1 in yachts ("Kiriacoulis Med.") (Athens SE); 4 in costal shipping ("Attica Holdings SA"; "Anek Lines SA"; "Minoan Lines" \& "Nel Lines"; "Blue Star Mar." taken-over by Attica); 1 shipyard ("Neorion of Syros"); 1 dealing with rigs (“Ocean Rigs"), and 31 ocean-going shipping companies. We see this time 6 marine companies to be in $\mathrm{SEs}^{39}$.

In more detail: "Navios Holdings" listed-in 3 more companies ("Navios Mar. Acquis.", "Partners" and "Midstream"). Also, we have 9 more companies: "Box Ships Inc." controlled by "Paragon" (its stock price was <\$1 in May 2016); “Dorian LPG Ltd" ( $\$ 18$ year's high stock price); “Dynagas LNG Partners" (\$21); "Euronav NV" (new issue at \$ 17); “Gaslog Ltd" (\$ 22); “Gaslog Partners" (\$ 28); “Genco Ship \& Trading” (\$ 8); “Gener8 Mar. Inc." (\$ 15); and "Pyxis Tankers Inc." (\$3.37). Eight companies ${ }^{40}$ in 2016 were already listed ${ }^{41}$ : “Omega"; "Ocean tankers"; "Eagle”; "Excel”; “Oceanaut”; "Hellenic Carriers"; “Aries” and "Oceanfreight".

6) The international picture, 2016

The situation in June $3^{\text {rd }}, 2016$, in global SEs, was as follows (Table 9).

As shown, in 2016, 162 marine companies reached a capitalization of $\$ 221 \mathrm{~b}$, against $\$ 31$ b in mid-1996! This shows an increase of above 7 times in 20 years! The shipping sector, excluding shipbuilding and cruises, had a capitalization ${ }^{42}$ of $\$ 94 \mathrm{~b}$ in 2016 or $\sim 42.5 \%$ of the total (companies noted by $\left(^{*}\right.$ ) in Table 9 plus “Euronav"), against $\$ 22.5 \mathrm{~b}$ in mid-1996. This is a rise of 4.2 times in 20 years. So, shipping companies found finally their way to SEs, but not all of them. This trend is expected to continue after the Pandemic is over, perhaps in 2022.

7) The top-10 shipping Greek-owned companies listed in 2018

For the top-10 Greek-owned listed shipping companies, 10 years after the crisis, in March 2018 (Figure 3), the picture was as shown.

As shown, the top 10 listed Greek shipping companies ${ }^{43}$, had a capitalization, in March, 2018, of $\$ 5.4$ b, due to the continued crisis of end-2008 extended to 2018.

8) Recapitulation

The progress of the listed Greek-owned shipping companies was positive since mainly 2005, but unfortunately, hit-down by the end-2008 crisis and they did not recover till 2020! (Table 10).

\footnotetext{
${ }^{39}$ Of the above 40, 8 companies listed in Athens, 31 in US and 1 in UK ("Goldenport").

${ }^{40} \mathrm{~A}$ split was done by "Paragon", "Diana Containerships", "Dryships”, "TOP Ships” and "FreeSeas”.

${ }^{41}$ "Globus Mar." left London and entered US SE, in 2010.

${ }^{42} \mathrm{We}$ did not count: the largest public companies in key sectors, except "Euronav"; shipbroking; shipbuilding; cruises; shipping services; and offshore.

${ }^{43}$ These companies are: Costamare; Star Bulk Carriers; Dryships; Capital Product Partners LP; \& Diana.
} 
Table 9. Capitalization of 162 marine companies worldwide, mid-2016.

\begin{tabular}{|c|c|c|c|c|c|}
\hline \multirow[t]{2}{*}{ Marine sector } & \multirow{2}{*}{$\begin{array}{l}\text { Number of } \\
\text { companies }\end{array}$} & \multicolumn{2}{|c|}{$\begin{array}{l}\text { Capitalization } \\
2016\end{array}$} & \multirow{2}{*}{ Remarks } & \multirow{2}{*}{$\begin{array}{l}\text { Average } \\
\text { capitalization }\end{array}$} \\
\hline & & $\$ \mathrm{~m}$ & $\%$ & & \\
\hline Dry Cargo & 34 & $10,802\left(^{*}\right)$ & $\sim 5$ & $\begin{array}{c}8 \text { Greeks; top: China } \\
\text { Merchants Energy-A } 3932 \mathrm{~m}\end{array}$ & $\$ 318 \mathrm{~m}$ \\
\hline Crude Tankers & 5 & $3838\left(^{*}\right)$ & & 1 Greek; top: Frontline 1357 m & $\$ 768 \mathrm{~m}$ \\
\hline Car carriers & 2 & $930\left(^{*}\right)$ & & Top: Wilhelmesen $\$ 845 \mathrm{~m}$ & $\$ 465 \mathrm{~m}$ \\
\hline Chemical carriers & 2 & $386\left(^{*}\right)$ & & Top: Team t. $\$ 272 \mathrm{~m}$ & $\$ 193$ \\
\hline Cruises & 1 & 16,455 & $\sim 7.5$ & Top: Royal Car. & $\$ 16.4 \mathrm{~b}$ \\
\hline Containerships & 19 & $21,411\left(^{*}\right)$ & $\sim 10$ & 4 Greeks; top: Cosco $\$ 6002 \mathrm{~m}$ & $\$ 1.13 \mathrm{~b}$ \\
\hline Diversified & 34 & $39,492\left(^{*}\right)$ & $\sim 18$ & $\begin{array}{c}6 \text { Greek; top: } \\
\text { China sh. Dev.-H } \$ 3383 \mathrm{~m}\end{array}$ & $\$ 1.16 \mathrm{~b}$ \\
\hline Product tankers & 7 & $4821\left(^{*}\right)$ & & 1 Greek; top: Hafnia $\$ 502 \mathrm{~m}$ & $\$ 689 \mathrm{~m}$ \\
\hline $\begin{array}{l}\text { Shipping master } \\
\text { Ltd partnerships }\end{array}$ & 8 & $1246\left(^{*}\right)$ & & $\begin{array}{l}3 \text { Greeks; top: Teekay LNG } \\
\text { Partners } \$ 1197\end{array}$ & $\$ 156 \mathrm{~m}$ \\
\hline $\begin{array}{l}\text { KG (Limited } \\
\text { partnerships) }\end{array}$ & 2 & $40\left(^{*}\right)$ & & Top: HCI Cap. $\$ 24 \mathrm{~m}$ & $\$ 20 \mathrm{~m}$ \\
\hline LNG carriers & 5 & $6956\left(^{*}\right)$ & & $\begin{array}{c}1 \text { Greek; } \\
\text { Top: Qatar Gas } \$ 3546 \text { m }\end{array}$ & $\$ 1.39 \mathrm{~b}$ \\
\hline LPG carriers & 7 & $2218\left(^{*}\right)$ & & $\begin{array}{c}2 \text { Greeks; top: } \\
\text { Navigator H Ltd } \$ 753 \mathrm{~m}\end{array}$ & $\$ 317 \mathrm{~m}$ \\
\hline Shipbroking & 1 & 195 & & Braemar & $\$ 195 \mathrm{~m}$ \\
\hline Shipbuilding & 13 & 27,727 & 12.5 & Top: Mitsubishi $\$ 13,695 \mathrm{~m}$ & $\$ 2.13 \mathrm{~b}$ \\
\hline Shipping services & 1 & 983 & & Fisher & $\$ 983 \mathrm{~m}$ \\
\hline $\begin{array}{l}\text { Largest companies } \\
\text { in key sectors }\end{array}$ & 9 & 81,789 & 37 & $\begin{array}{l}1 \text { Greek: Euronav } \$ 1634 \mathrm{~m} \text {; top: } \\
\text { Carnival in Cruises } \$ 35,967 \mathrm{~m}\end{array}$ & $\$ 9.09 \mathrm{~b}$ \\
\hline $\begin{array}{l}\text { Offshore sup. } \\
\text { Vessels (OSVs) }\end{array}$ & 12 & 1940 & & Top: Seacor $\$ 977$ m & $\$ 162 \mathrm{~m}$ \\
\hline Total 17 sectors & $\begin{array}{c}162 \\
\text { companies }\end{array}$ & $\$ \sim 221 \mathrm{~b}$ & & Ocean going: $\$ 94 \mathrm{~b}$ & \\
\hline
\end{tabular}

Source: Gong et al., 2006; the last column gave the average capitalization per company over 17 marine sectors $^{44}$.

Table 10. The progress of Greek-owned shipping companies' IPOs, 2005-2008.

\begin{tabular}{cccc}
\hline Year & Number of companies & Amount raised in \$ b & $\%$ \\
\hline 2005 & 26 & 2.48 & \\
2006 & 20 & 11.00 & A 4.2 times rise \\
2007 & 28 & 15.40 & +46 \\
2008 Jan. & 25 & 21.00 & +37 \\
2008 Nov. & 25 & 7.00 & -67 \\
2008 end & 25 & 5.5 & -21.4 \\
\hline
\end{tabular}

Source: text.

${ }^{44}$ This proves that 18 Greek shipping companies out of 25 are below the average capitalization of their sector and competitors, in end-2008 and thereafter. 


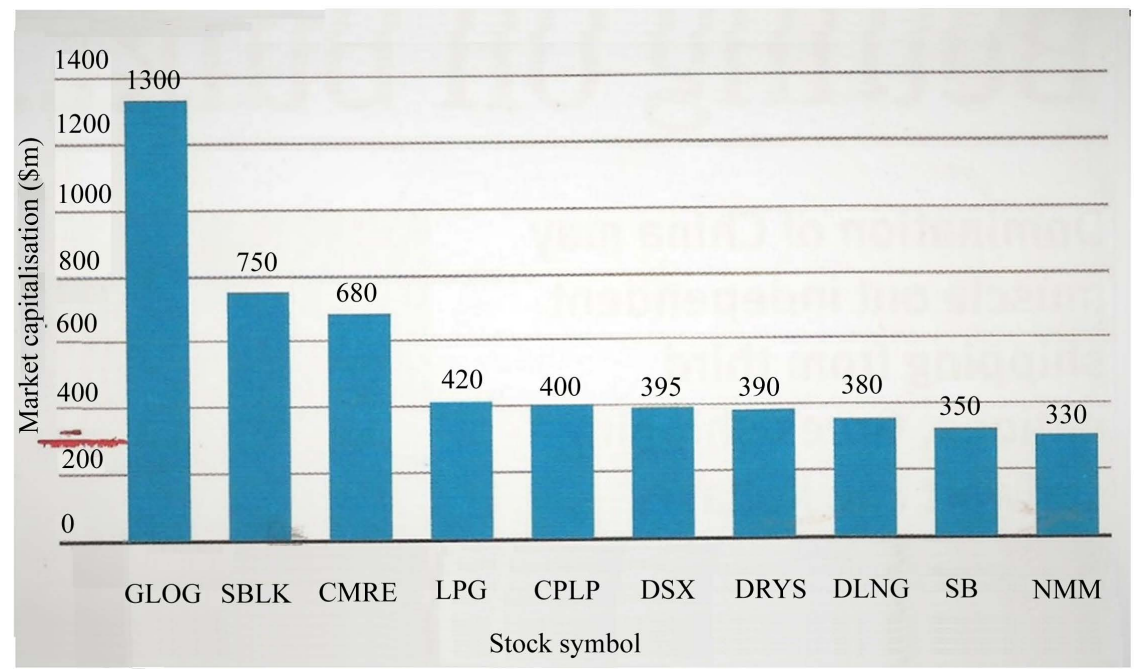

Figure 3. The capitalization of the top 10 Greek shipping companies listed in March 2018 in Wall Street. Source: Lloyd's List Intelligence; modified ${ }^{45}$.

\section{Play with Shipping Assets: A Science or a Game?}

\subsection{The Asset Play Theory}

Graph 1 illustrates the practice of shipping asset play, which originated in Norway, and became very popular there, about 30 years ago.

The success of the asset play depends on the degree of assets' appreciation, like the one which happens to houses. Stopford (2009) noted (p. 328) that a "model company", he constructed, owned 20 ships, which were bought with $\$ 162 \mathrm{~m}$ in 1975 , and as time passed-by, their market value increased ${ }^{46}$ to $\$ 740 \mathrm{~m}$ (after 31 year $^{47} ; 4.6$ times)! Those that say that time is money are indeed right!

Figure 4 plots the "capital gains and losses" of a shipping company, which we will call: "Stopford's Perfect shipping company"-SPS.

As shown (Figure 4), all 30 years did not provide capital gains, only 18 years did (60\%): and exceptionally: 2002-2004 and 2006.

\subsection{Corollary One}

Shipping, due to its asset appreciation, needs lenders with a rather long, (at least $8^{48}$ years), patience so that to finance a ship from her time of acquisition, or delivery, till her end (scrapping) or sale. Ships are like wines; they have to be left to mature! If a loan does not take into account the whole cyclical life of a vessel, it is going to harm her shipowner-customer, due to a myopic finance policy. Most

\footnotetext{
${ }^{45} \mathrm{GLOG}=$ Gaslog; Star BC Corp. $=$ SBLK; CMRE $=$ Costamare; $\mathrm{LPG}=$ Dorian; Capital Pr. Partn.s = CPLP; DSX = Diana sh.; DRYS-Dry Ships; DLNG = Dynagas; $\mathrm{SB}=$ safe bulkers and NMM $=$ Navios Mar. Partners.

${ }^{46}$ Stopford in his SPS model assumed a change of company's fleet every 10 years, perhaps to avoid the heavy cost of the $3^{\text {rd }}$ drydocking/survey at about 12 years. This was a practice of the British shipowners (Goulielmos, 1974).

${ }^{47}$ In case ships have a long life, they may have to be sold before their end, and there will be capitai gains, but also losses. In SPS case $\$ \mathbf{5 7 7} \mathrm{m}$ was the final capital gain!

${ }^{48}$ This cycle period is calculated by Stopford as equal to 8 years on average.
} 


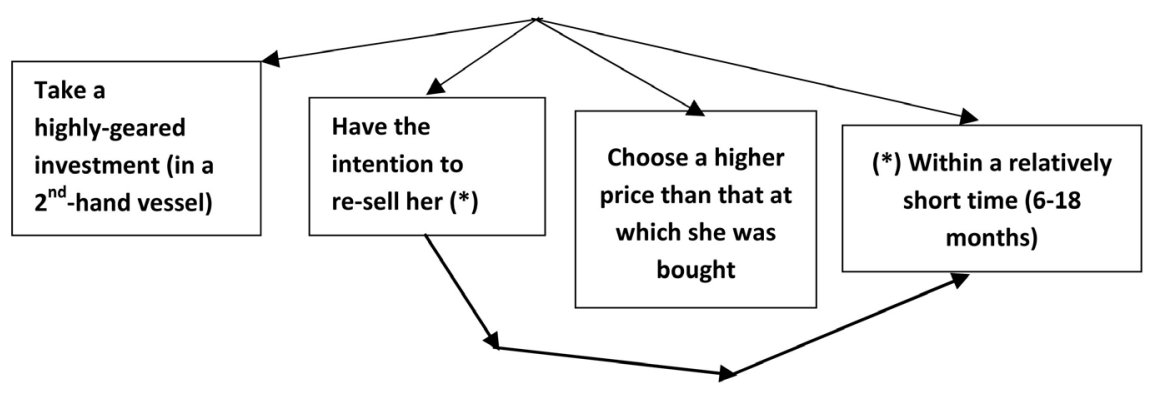

Graph 1. The "asset play" with ships. Source: author.

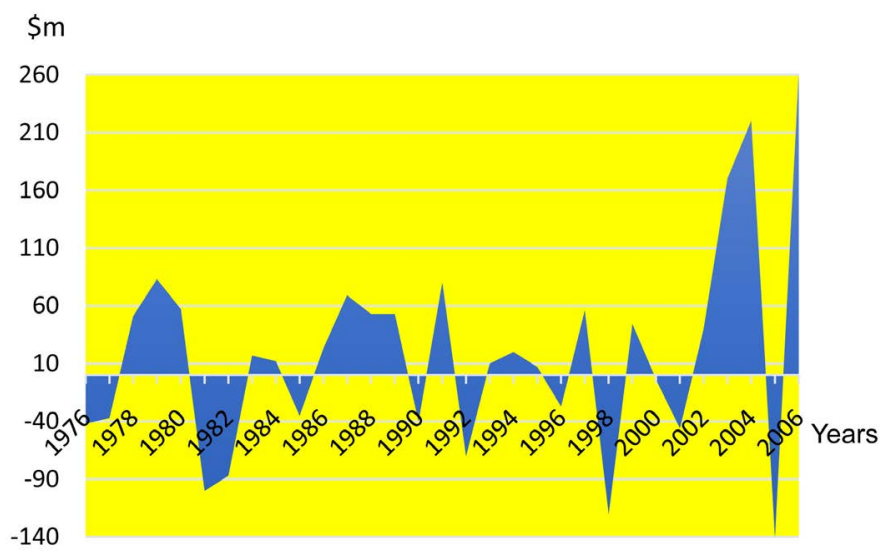

Figure 4. Capital gains and losses, 1976-2006, of SPS. Source: Data from Stopford (2009: p. 327).

bank finance deals last only 4 years! The "asset play" is better to be applied to a ship over her full economic life, (round 30 - 32 years on average), in which the company has a rather high $\%$ of ownership, and depreciation, so that to be worth the trouble of selling (covering also the commissions involved).

\subsection{Further on Asset Play}

For us, asset play concerns all kinds of ships, including newly-built ones. Some shipping companies build ships specifically for asset play, called "options". Now, to distinguish the ships bought for "asset play" from those bought/built for renewal or growth, one needs the relevant intention to be pre-stated, something difficult! One post-fact indication, therefore, is to sell these ships for asset play soon after they have been acquired, proving indirectly company's original intention, not to retain them in the fleet, but to sell them for asset play...

Stokes argued that a 6-to-18-months-period is required between buying and selling to consider an act as an asset play. For us, there is always a proper timing, called perfect timing, to buy and sell ships, with a view to maximize the difference between the price at which the asset bought ${ }^{49}$ and the net price finally at which she was sold.

${ }^{49}$ This price is increased (or reduced) for possible repairs and improvements increasing the value (capital) of the ship like for example a 4-year drydocking. 


\subsection{Corollary Two}

Potential asset play must be taken into account by both banks and SEs as it is an essential part of shipping business, and exceptionally profitable (Figure 5), though, as mentioned, is not shipowner's core business.

As shown, the price ${ }^{50}$ of a newly-built bulk carrier of 60,000 dwt and her sister, 5-years old, reached their top prices in 1991: \$37 m and \$24 m respectively ( $\$ 61$ $\mathrm{m})$. Thus, a perfect year to sell is clearly 1991. Assuming that these ships were built and bought in 1985 (6 years back) at $\$ 12 \mathrm{~m}$ and $\$ 4 \mathrm{~m}$ respectively (=\$16 $\mathrm{m})$, and depreciated $\left(1 / 20^{\text {th }}\right.$ p.a.) with $\$ 3.6 \mathrm{~m}$ and $\$ 1.2 \mathrm{~m}$ each (assuming a 20 -year hypothetical life) (=\$4.8 m), the net profit from selling them is: $\$ 28.6 \mathrm{~m}$ and $\$ 21.2 \mathrm{~m}$ respectively (a total capital gain of $\$ \sim 50 \mathrm{~m}$ )! One may argue that the above is not an asset play, as 6 years have elapsed between buying (delivering) and selling. Yes, but it provided a handsome profit, effortless, of $\$ \sim 50 \mathrm{~m} .$.

\subsection{Corollary Three}

Most important is to realize that volatility created the above profit...! Ordering in 1985, and selling in 1991, after delivery in 1987, one had a 4-yearly depreciation, which increased the capital gain by almost $\$ 5 \mathrm{~m}$. Depreciation, however, depends on profits. Thus, volatility is a blessing and a curse at the same time... For us is a blessing, if it is followed by perfect timing.

\subsection{The Future NAV}

SEs, and banks, do not pay attention at all in future $\mathrm{NAV}^{51}$, something, we believe, altogether unfair! We will examine a couple of case-studies.

1) The case study of a representative shipping company

Figure 6 presents a representative shipping company, with actual figures, for 1991-1995, assuming to own 8 different types of vessels (2 VLCCs, of which one modern, and most profitable; 1 Suezmax; 1 Aframax; 1 for clean products; $1 \mathrm{Ca}$ pesize, and most profitable; 1 Panamax; and 1 Handymax (trip))!

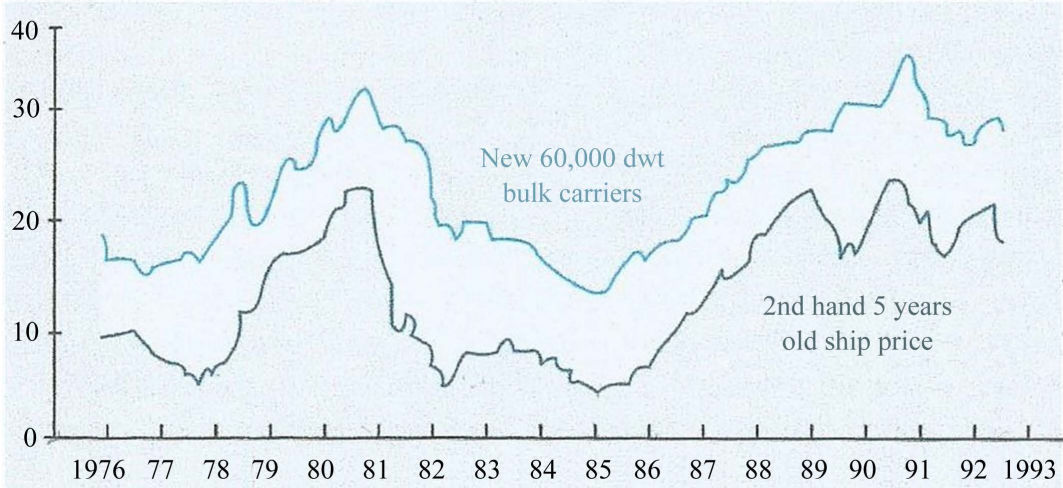

Figure 5. Prices of a $2^{\text {nd }}$ hand vessel of 60,000 dwt bulk carrier 5-years old and a newly-built sister one, 1976-1993. Source: Stopford (2009).

${ }^{50}$ These 2-time series move similarly, meaning that a $3^{\text {rd }}$ factor determines both (i.e., freight rate).

${ }^{51}$ Banks study 3 past yearly balance sheets. 


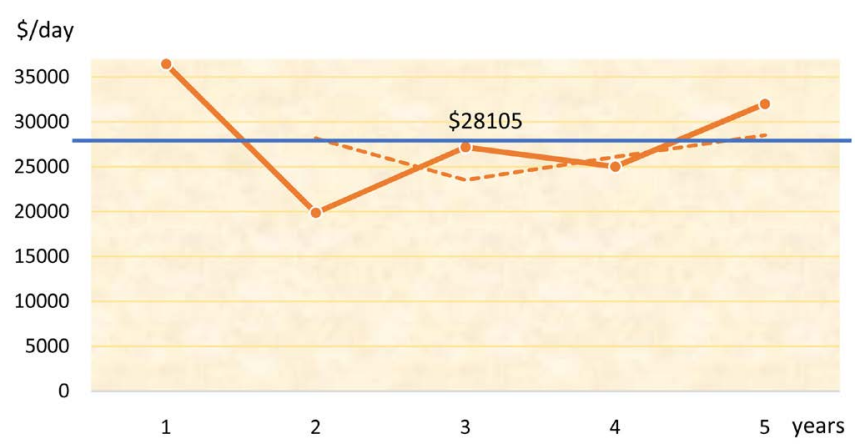

Figure 6. Gross average earnings of a representative shipping company, 1991-1995. Source: Data from Stokes (1997: p. 185).

First, the cyclicality of earnings is obvious: the change in daily gross average earnings from year to year varied from $\$ 36,449 /$ day (high) to $\$ 19.862 /$ day (low) (1991-1992) ( 55\%). Our first proposal to banks and SEs, is, if they want to finance the above excellent company, to take into account its (gross) average earnings for the last 5 years, i.e., \$28,105 (for 350 days), and not its 1991 daily earnings (of $\$ 36,449$ ), as actually do. Still this company is in a disadvantageous position, because its economic life taken is 5 and not 8 years, which is its one full shipping cycle.

The secret behind the above case-study is that if a loan/IPO is based on the 1991 average earnings, the company will be unable to re-pay/return it in next 5 years! But if the loan is based on its average earnings, the company will be able to repay it! Of course, the amount of the loan/IPO will be different in the two cases: in the 1st case the loan amount will be $\$ \sim 64 \mathrm{~m}$; in the $2^{\text {nd }}$ version, the loan/IPO will be $\$ \sim 49$, ignoring operating costs. Of course, if one still wants to lend $\$ 64 \mathrm{~m}$, then the tenor in the $2^{\text {nd }}$ version will have to be extended by no more than 18 months.

2) The SPS Company Case-Study

Figure 7 presents 31 years of business of the SPS company. Obviously, there are several cycles: long and short. Banks/IPOs-according to our anti-cyclical theory-must take into account the bottom (\$ 5000/day) level of gross earnings (per day), and then provide accordingly a loan/an IPO.

Assume now that the SPS company asks for a loan in 1977; the bank sees that its gross earnings per day are $\$ 3814$, and by assuming, for simplicity, zero operating costs, provides a loan of $\$ 7 \mathrm{~m}$ for 5 years. But market all next 29 years has improved!

Suppose now, that the same bank had a loan application in 2004, by the same company, where gross earnings were at $\$ 31,681$ per day or $\$ \sim 11 \mathrm{~m}$ p.a. The bank agrees (common among banks) to lend $\$ \sim 55.5 \mathrm{~m}$ over 5 years. But given that gross earnings fell in 2005 to $\$ 8 \mathrm{~m}$ p.a., and in 2006 to $\$ 7.5 \mathrm{~m}$, the contribution of earnings to loan repayment of these 2 years will be only $\$ 41.5 \mathrm{~m}$ (assuming same earnings for the last 3 years, 2006-2008). Thus, the company will be unable to repay its loan of $\$ 55.5$ and it will be in default for $\$ 14 \mathrm{~m}$ ! For the sake of simplicity, we ignored interest charges. 


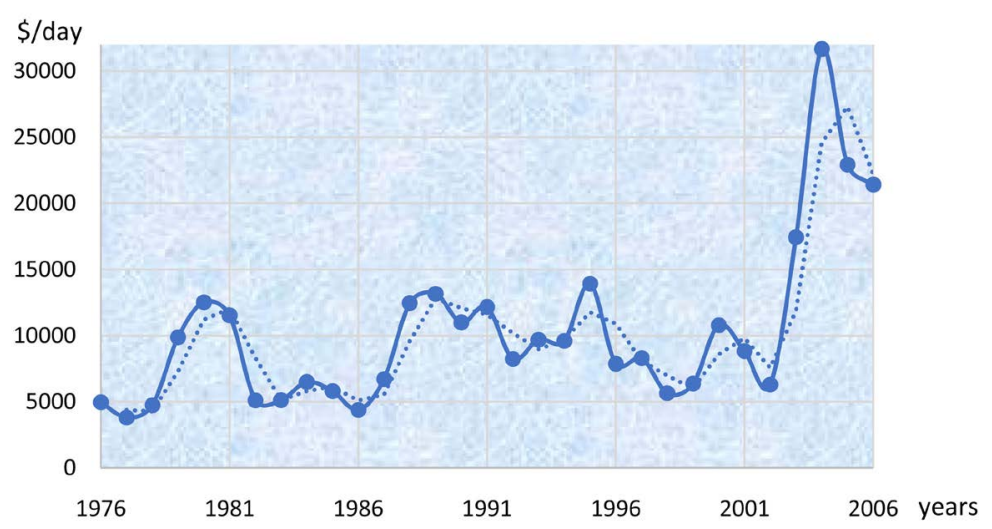

Figure 7. Spot earnings \$/day 1976-2006 for a standard fleet of 20 ships of SPS. Source: based on data from Stopford (2009: p. 327).

3) The Net asset value

Banks and SEs take into account past NAVs. In Figure 8, we plotted the NAVs of SPS company.

As shown, the best year (perfect timing) for an IPO was 2004! Certain Greeks-as we saw-chose 2005, wrongly... Figure 8 indicates 2 cycles: 1975-1988 (14 years) and 1989-2002 (14 years), at two different levels. Suppose now that a company tried an IPO at its 1975 value of $\$ 162 \mathrm{~m}$ and issued $10 \mathrm{~m}$ shares (=\$16.2 each); in ten years' time, this value fell to $\$ 9.5 /$ share (1984), and in another 10 years this went-up to \$ 39 (1994)!

\subsection{Corollary Four}

Given that an IPO or a bank loan are related to a company's future course, the omission to disregard a series of future NAVs, is at least unfair. Given also that a forecasting is impossible, we next recommend to SEs and banks to apply the method of visioning belonging to Chaos theory, as shown below.

\section{Visioning Company's Future Earnings and NAVs}

The serious volatility of shipping NAVs should not lead one to refuse its finance, but it is better to apply visioning and perfect timing ${ }^{52}$ ! This is our theory. We will apply visioning for company's future, but not forecasting, because we consider it to be impossible ${ }^{53}$, as mentioned (Goulielmos, 2020). For this endeavor, we will apply Chaos Theory (Priesmeyer, 1992: Chap. 8).

Any (shipping) company has a number of structural characteristics, and these are determined by its management, which this way it defines its performance: The structural characteristics for shipping companies, in or opinion, are: 1) the time of buying or ordering ships, 2) the total cost of fleet operation, 3) the type

${ }^{52}$ Perfect timing in shipping is when ship prices (new; $2^{\text {nd }}$ hand) reached rock bottom levels and at delivery freight rates will be at maximum. Then sales dispose older and smaller ships and buy newer and larger.

${ }^{53}$ As put by Priesmeyer (1992: p. 176), "forecasting is the process of using historical data exclusively to make estimates of the future, which fails to acknowledge the presence of free will". 


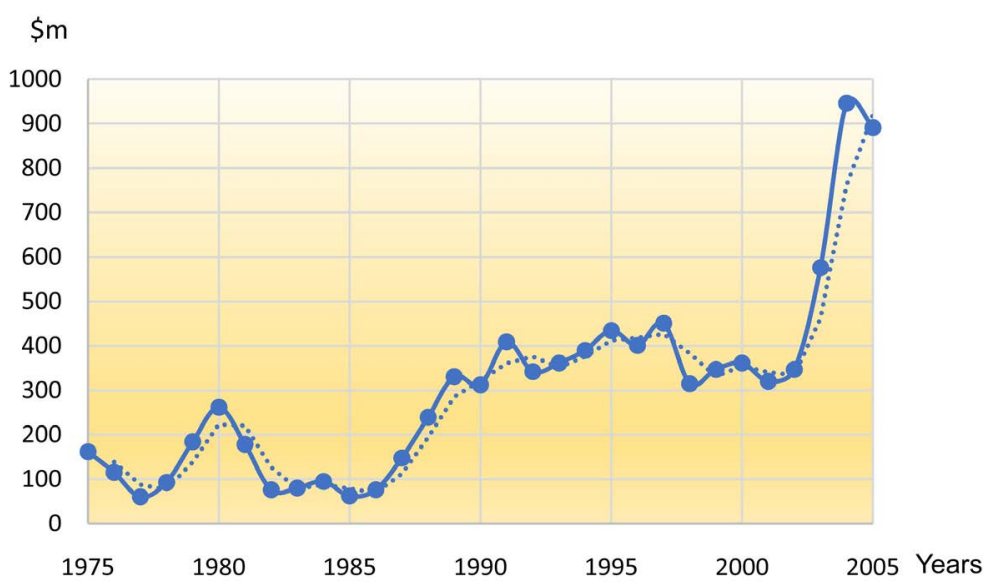

Figure 8. The NAVs of SPS company, 1975-2005. Source: data from Stopford (2009: p. 327).

of chartering (spot or time), 4) the fleet's gross earnings, 5) the manner fleet financed and 6) liquidity.

Visioning, now, is the process of... defining a company's future. The state of a shipping company is determined by its (initial) fleet and the forces, which act on it, (i.e., the freight markets ${ }^{54}$ ). We have, however, to act on these forces to create our visioned condition... First, we need to draw a "phase plane ${ }^{55 ",}$ and prepare the statistics associated with the company (SPS company) (Appendix). The phase plane (Graph 2) is a (full) Cartesian figure, meaning that we have to use all its 4 quadrants. Also, changes in variables will be used, and not absolute figures (Appendix).

As shown, we plotted the trajectories of the changes of the 2 basic factors of the SPS company, for the last 4 years ${ }^{56}, 2003-2006$ (Appendix): changes in gross earnings (the independent variable) and changes in NAVs (the dependent variable). First, we see something important: company's trajectories visited the 1131 quadrants, meaning a low order chaos (Priesmeyer, 1992: p. 40) (a period-2 limit cycle $\left.^{57}\right)$ !

Because this low order chaos shows a level of stability, banks and SEs must take this into account. This class covers the $2^{\text {nd }}$ serious percentage of cases (32\%). Second, the year gross earnings rose by $\$ 3.9 \mathrm{~m}$ and by $\$ \sim 5 \mathrm{~m}$ from 2003 to 2004 , then fell by $\$ \sim 3.1 \mathrm{~m}$ in 2005 and rose by $\$ 0.53 \mathrm{~m}$ in 2006 . The company

\footnotetext{
${ }^{54}$ The condition of the freight market is determined by the total supply of ship spaces (dwt) and the demand for it, with a view to transport a cargo by sea from port A to port B. For the demand to be influenced by a single company is impossible; supply may be influenced, if a single company builds a few million dwt (cases of Sanko \& Eletson companies). Thus, pure competition is applied if supply is not influenced.

${ }^{55}$ The phase plane, or space, is a mathematical space, where trajectories cover past, future and present.

${ }^{56}$ Priesmeyer (1992) argued that this procedure involves comparing the sequence of the 4 most recent quadrant visits.

${ }^{57}$ The period 2 limit Cycles present a simple oscillation when one variable changes, as in here gross earnings, while NAV remains rather constant. It is also common to have gross earnings and NAVs to change proportionally in such cases.
} 


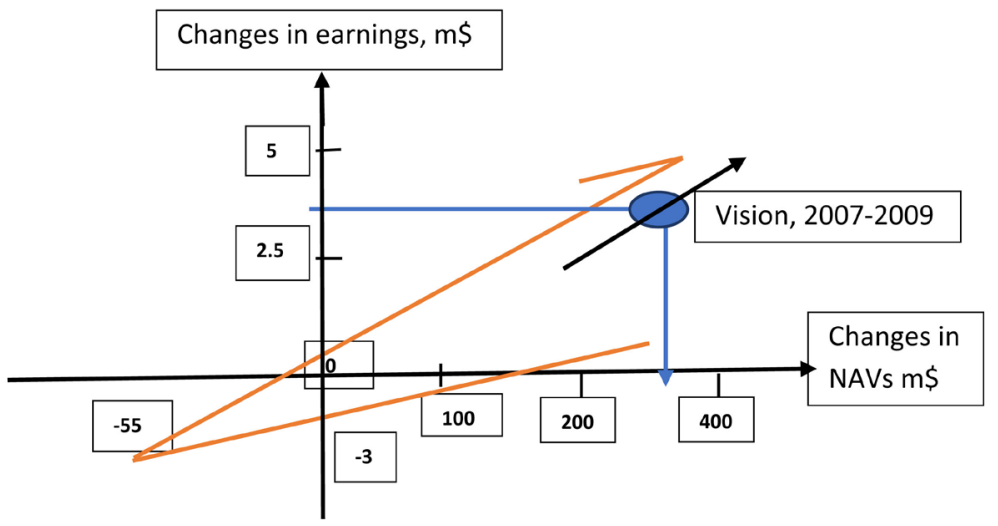

Graph 2. Visioning SPS company by Chaos theory, 2003-2006. Source: Table A1 in Appendix.

then pursued its vision denoted by the blue dot: i.e., to achieve $\$ 30,000 /$ day gross earnings and a \$330 m a NAV change in 2007 and in 2007-2009. Can SPS company do that?

Stopford (2009: pp. 325-329) wrote that the gross earnings of the SPS company came from the spot market. This means that the company has immediately to turn to time charters, to achieve this $\$ 30,000 /$ day ( $\$ 10.5$ m per year) visioned; this is lower by $\$ 1681 /$ day ( $\$ 0.59 \mathrm{~m}$ p.a.) than the previous year! Management should have realized that spot earnings were falling (as they did: to about $\$ 23,000 /$ day in 2005 from $\$ 232,000$ in 2004)!

The help of Graph 2 is such that if gross earnings start to fall, it tells us to act fast... to "stop" it. We saw many Greek-owned shipping companies to turn to time charters as market falls... but at their earlier convenience. This turn will provide $\$ 3 \mathrm{~m}$ for 2007 and $330 \mathrm{NAV}$, both visioned for each of the next 3 years: 2007-2009.

The above outcome, gives now the company's visits in 1111 quadrants for 2006-2009, meaning period 1 chaos! This is attained by only 4 cases out of 256 in theory. Visioning improved company's order of chaos! This vision is feasible as company has achieved it 3 times in the recent past (visit in upper right-hand quadrant where both variables rise). Apparently, the company had to find longer time charters than the 3 years we assumed, say another 4 years to pass most of the crisis period of 2010-2022!

Finally, the SPS company failed to achieve a perfect timing in deliveries and purchases of ships-as noted in Figure 7 above. We remind the reader for this important finding using Figure 9. This is a structural characteristic, as mentioned. Moreover, by using gross earnings, we could not take into account the management of operating costs, which is as well one important structural characteristic of shipping companies.

As shown, the best years to buy are eight, indicated by the blue arrows (1977; 1982-1986; 1998; 2001). The years to sell are also shown by the red arrows and are also eight. 


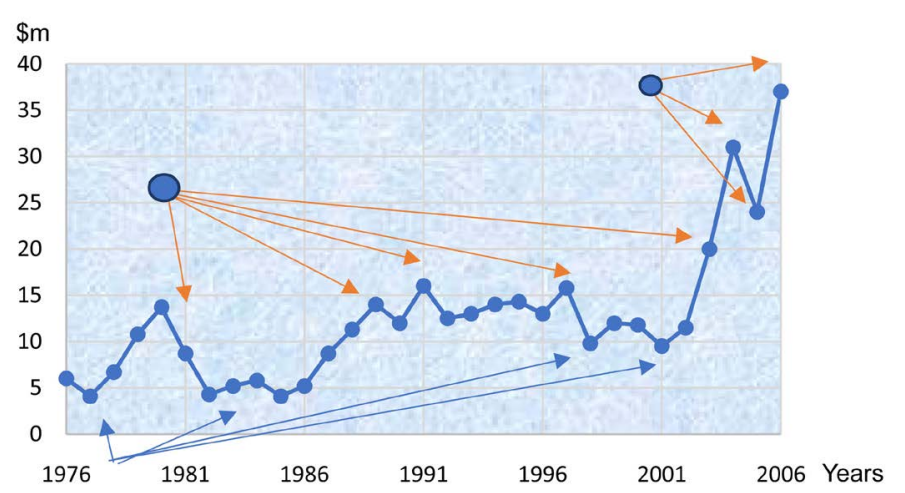

Figure 9. The price of a 10-year old ship, \$m, 1975-2006. Source: data from Stopford (2009: p. 327).

\section{Conclusion}

Our contribution to the whole issue, which could be titled in a short sentence as: "Shipping Industry in international Stock Exchanges: problems and solutions", is that there is no other of its kind, giving a historical account of this important step and marking-out the advantages and disadvantages.

More important was, however, to gather data and show what a global financial crisis could do to the capitalization of the companies and particularly of Greek-owned ones, losing 2/3 of their value! Moreover, we provided a lengthy analysis on shipping asset play. In addition, what we consider unique contribution of our work is to show that volatility and cyclicality in shipping sector are a blessing for those who understand shipping, and unfortunately in those are not neither the banks or the Stock Exchanges!

Last but not least we showed that to be in a Stock Exchange as Greeks shipowners did in 2005, massively for the first time, one may lose company's management! Can one do that if ship-owning and ship-management are a way of life?

We showed that finance/IPOs based on earnings at rock bottom (1977) is safer than that based on top earnings (2004). Our experience from Greek shipowners and SEs tells us that companies, wanting to be listed, have to be trained about it in advance, as they have no previous experience. Important in SEs, no doubt, is the stock price, during an IPO, but also it in the aftermarket. This price may disappoint shipping companies, if it is below their average NAV.

The impact of the GFC-global financial crisis on shipping stocks was detrimental as in Jan. 2008, 25 Greek-owned listed shipping companies capitalized at $\$ 21 \mathrm{~b}$ and in end-2008 capitalized at $\$ 7 \mathrm{~b}$ ! Thus, they lost $\$ 14 \mathrm{~b}(67 \%)$. In a crisis, the risk to be taken-over by another company is very high. This is the main reason for Greek-owned shipping companies not to resort to SEs for finance. Another important disadvantage of SEs is that they ignore the future NAVs of the companies, and their potential asset play. Given the general inability to forecast due to human free will, banks and SEs treat shipping companies unfairly!

SEs provide great services as they transform fixed investments into liquid 
ones; and in addition, one may change his/her profession at will (Keynes, 1936: chap. 12)... They also protect investors as trading below $\$ 1$ for 30 consecutive trading days is not allowed; 7 Greek shipping stocks reached this in 2016. When companies hit the low limit of the stock price of $\$ 1$, they decide to split ${ }^{58}$ their shares to regain compliance. "Hellenic C" joined "Goldenport" abandoning SE, due to the costs of being listed.

Banks, no doubt, dominate as a source of finance to Shipping Industry. Unfortunately, both banks and SEs are apparently unfamiliar with Shipping Cycles and Volatility! This lack of familiarity with cycles, and volatility, transforms, at times, we believe, banks and SEs investors from yesterday's enthusiastic partners to present day bitter opponents!

The end-2008 period provided a good opportunity for those having the funds, to buy a few-most profitable-shipping companies, at $1 / 3$ of their previous and very recent value! This means that companies have to maintain higher than hitherto depreciation rates and to distribute lower dividends... so that to build crisis reserves as a recession starts. A crisis will oblige one to resort to them again, but what if they refuse to give, confused by volatility and not understanding the asset play using ships?

\section{Conflicts of Interest}

The author declares no conflicts of interest regarding the publication of this paper.

\section{References}

Apergis, N., \& Sorros, J. (2010). Disaggregated Earnings and Stock Prices: Evidence from International Listed Shipping Firms. International Advances in Economic Research, 16, 269-281. https://doi.org/10.1007/s11294-010-9263-2

Drobetz, W., Schilling, D., \& Tegtmeier, L. (2010). Common Risk Factors in the Returns of Shipping Stocks. Maritime Policy \& Management, 37, 93-120. https://doi.org/10.1080/03088830903533726

Gilpin, A. (1986). Dictionary of Economic and Financial Markets (5th ed.). London: Butterworths.

Gong, S. X. H., Firth, M., \& Cullinane, K. (2006). Beta Estimation and Stability in the US-Listed International Transportation Industry. Review of Pacific Basin Financial Markets and Policies, 9, 463-490. https://doi.org/10.1142/S0219091506000811

Goulielmos, A. M. (1974). A Vintage Model Approach to Some Problems of Shipping Economics. Unpublished Doctoral Thesis, Uxbridge: Brunel University.

Goulielmos, A. M. (2020). The Investment Strategy and the Growth Policy of Greek Shipowners Revealed, 1946-2020. Modern Economy, 11, 1858-1886. https://doi.org/10.4236/me.2020.1111125

Goulielmos, A. M., Giziakis, C. V. \& Palari, V. (2011). Advantages and Disadvantages of Managing Own Ships by a Third Party Ship Management Company: An Empirical In-

${ }^{58}$ Companies divide their outstanding shares into a larger number of shares, e.g., 3 for 1 split for a company of $1 \mathrm{~m}$ shares, means $3 \mathrm{~m}$. This sometimes is done for the stock price to be accessible when it underwent a substantial rise. For the above situation, we believe 2 or more new shares are replaced by 1 old. 
vestigation. International Journal of Shipping and Transport Logistics, 3, 126-150. https://doi.org/10.1504/IJSTL.2011.039375

Goulielmos, A. M., Goulielmos, M. A., \& Gatzoli, A. (2009). The Accident of Passenger-Car Vessel Samina Express (2000), When 80 Persons Died: An Analysis by the Principle of Nonlinear Management. Disaster Prevention and Management Journal, 18, 338-358. https://doi.org/10.1108/09653560910965682

Grammenos, C. T., \& Arcoulis, A. (2002). Macroeconomic Factors And international Stock Returns. International Journal of Maritime Economics, 4, 81-99.

Grammenos, C. T., \& Marcoulis, S. N. (1996). A Cross-Section Analysis of Stock Returns: The Case of Shipping Firms. Maritime Policy \& Management, 23, 67-80. https://doi.org/10.1080/03088839600000053

Kavussanos, M. G., \& Marcoulis, S. N. (1997a). Risk and Return of US Water Transportation Stocks over Time and over Bull and Bear Market Conditions. Maritime Policy \& Management, 24, 145-158. https://doi.org/10.1080/03088839700000066

Kavussanos, M. G., \& Marcoulis, S. N. (1997b). The Stock Market Perception of Industry Risk and Microeconomic Factors: The Case of the US Water Transportation Industry versus Other Transportation Industries. Transportation Research Part E: Logistics and Transportation Review, 33, 147-158. https://doi.org/10.1016/S1366-5545(97)00015-X

Kavussanos, M. G., \& Marcoulis, S. N. (1998). Beta Comparisons across Industries: A Water Transportation Industry Perspective. Maritime Policy \& Management, 25, 175-184. https://doi.org/10.1080/03088839800000027

Kavussanos, M. G., \& Marcoulis, S. N. (2005). Cross-Industries Comparisons of the Behavior of Stock Returns in Shipping, Transportation and Other Industries. Research in Transportation Economics, 12, 107-142. https://doi.org/10.1016/S0739-8859(04)12004-0

Kavussanos, M. G., Juell-Scielse, A., \& Forrest, M. (2003). International Comparison of Market Risks across Shipping-Related Industries. Maritime Policy \& Management, 30, 107-122. https://doi.org/10.1080/0308883032000069271

Keynes, J. M. (1936). The General Theory of Employment Interest and Money. London: Macmillan \& Co Ltd.

Mandelbrot, B. B., \& Hudson, R. L. (2006). The (mis)Behavior of Markets: A Fractal View of Financial Turbulence. New York, NY: Basic Books.

Priesmeyer, H. R. (1992). Organizations and Chaos: Defining the Methods of Nonlinear Management. Westport, Connecticut-London: Quorum Books.

Stokes, P. (1997). Ship Finance: Credit Expansion and the Boom-Bust Cycle (2nd ed.). London: LLP-Lloyd's of London Press.

Stopford, M. (2009). Maritime Economics (3rd ed.). London: Routledge. 


\section{Appendix}

Table A1. Phase plane.

\begin{tabular}{ccc}
\hline Year & $\begin{array}{c}\text { Spot Earnings \$/day, difference } \\
\text { from previous year-year data }\end{array}$ & $\begin{array}{c}\text { NAV-Net asset value, } \\
\text { difference from previous year }\end{array}$ \\
\hline 2002 & $6308 /$ day & $\$ 347 \mathrm{~m}$ \\
2003 & $6308-17,451=\$ 3.9 \mathrm{~m}$ & $347-576=\$ 229 \mathrm{~m}$ \\
2004 & $17,451-31,681=\$ 4.98 \mathrm{~m}$ & $576-946=\$ 370 \mathrm{~m}$ \\
2005 & $31,681-22,931=$ minus $\$ 3.1 \mathrm{~m}$ & $946-891=$ minus $\$ 55 \mathrm{~m}$ \\
2006 & $22,931-21,427=$ minus $\$ 0.53 \mathrm{~m}$ & $1221-891=\$ 330 \mathrm{~m}$ \\
\hline
\end{tabular}

Source: Data from Stopford (2009): SPS Co. 